University of Rhode Island

DigitalCommons@URI

Open Access Master's Theses

1995

\title{
A Feasibility Study for the Proposed Research Golf Course and Learning Center at the University of Rhode Island
}

Thomas C. Fanning

University of Rhode Island

Follow this and additional works at: https://digitalcommons.uri.edu/theses

\section{Recommended Citation}

Fanning, Thomas C., "A Feasibility Study for the Proposed Research Golf Course and Learning Center at the University of Rhode Island" (1995). Open Access Master's Theses. Paper 670.

https://digitalcommons.uri.edu/theses/670

This Thesis is brought to you for free and open access by DigitalCommons@URI. It has been accepted for inclusion in Open Access Master's Theses by an authorized administrator of DigitalCommons@URI. For more information, please contact digitalcommons-group@uri.edu. 
A FEASIBILITY STUDY FOR THE PROPOSED

RESEARCH GOLF COURSE AND LEARNING CENTER

AT THE UNIVERSITY OF RHODE ISLAND

BY

THOMAS C. FANNING

A RESEARCH PROJECT SUBMITTED IN

PARTIAL FULFILLMENT OF THE REQUIREMENTS

FOR THE DEGREE OF MASTER OF COMMUNITY PLANNING

UNIVERSITY OF RHODE ISLAND

1995 
MASTER OF COMMUNITY PLANNING

RESEARCH PROJECT

OF

THOMAS C. FANNING

Approved: Fa jor Professor: Thad Ptah

Dr. Farhad Atash

Acknowledged: Falla Ding

Dr. Farhad Atash 


\section{ACKNOWLEDGEMENTS}

There are several people I wish to thank for their help in completing this study. First, my advisor and friend Dr. Farhad Atash whose professional guidance was instrumental in the development and format of this entire project. His cheerful assistance and frequent counsel are largely responsible for the successful completion of this study. Second, I would like to thank Mr. Barry Devine and Professor Richard Casagrande for both the opportunity to participate in this project, and their insightful review and commentary. Third, Mr. David Westcott is also due many thanks for his meticulous editing skills and helpful suggestions, particularly in the environmentally sections of the study. Fourth, a special thanks also to Dr. Timothy Tyrrell whose advice and research was extremely helpful during the market analysis portion of this study. Finally, I would like to extend my appreciation to my family, particularly my wife Carolyn, whose support, encouragement, patience, and hard work made it possible to pursue a graduate degree at the University of Rhode Island. 
Acknowledgements

List of Tables

vii

List of Figures

viii

\section{CHAPTER ONE - INTRODUCTION}

1.0 Introduction and Project Overview 2

1.0.1 Project Objectives 3

1.0.2 Project Layout and Key Features 4

1.1 Purpose/Objectives of the Feasibility Study 9

1.2 Significance of the Feasibility Study 9

$\begin{array}{lll}1.3 & \text { Methodology/Approach } & 10\end{array}$

1.3.1 Objective \#1 - Site Inventory \& Analysis 10

1.3.2 Objective \#2 - Market Analysis 12

1.3.3 Objective \#3 - Financial Assessment 13

1.4 Limitations of the study 14

1.5 References 16

CHAPTER TWO - PROFILE OF THE UNIVERSITY

2.0 Introduction 18

$2.1 \quad$ The Early Years, 1892 - $1945 \quad 18$

2.2 The Post War Years, 1945-75 21

2.3 Recent Trends, 1975-91 23

2.4 The Carother's Administration, 1991 - Present 24

2.5 Summary of Findings 25

$2.6 \quad$ References 27

CHAPTER THREE - SITE DELINEATION AND REGULATORY REVIEW

$\begin{array}{lll}3.0 & \text { Introduction } & 29\end{array}$

3.1 Site Delineation 29

$3.2 \quad$ Site Description 32

3.3 Regulatory Requirements and Issues 33

3.3.1 Federal Regulations 34

3.3.2 State Regulations 35

3.3.3 Local Regulations 35

3.4 Summary of Findings 36

$3.5 \quad$ References 38 
CHAPTER FOUR - SITE INVENTORY AND ANALYSIS

$\begin{array}{lll}\text { 4.0 } & \text { Introduction } & 40 \\ 4.1 & \text { Environmental Inventory \& Constraints Analysis } & 40 \\ 4.1 .1 & \text { Topography } & 40 \\ 4.1 .2 & \text { Surface and Ground Water } & 42 \\ 4.1 .3 & \text { Soils } & 45 \\ 4.1 .4 & \text { Vegetation } & 51 \\ 4.1 .5 & \text { Constraints Map and PCP Comparison } & 53 \\ 4.2 & \text { Manmade Site Constraints } & 54 \\ 4.2 .1 & \text { Utilities and Services } & 54 \\ 4.2 .2 & \text { Circulation and Access } & 55 \\ 4.2 .3 & \text { Summary of the EPA Final Listings Report } & 58 \\ 4.3 & \text { Implications of the EPA Final Listings Report } & 61 \\ 4.4 & \text { Summary of Findings } & 64 \\ 4.5 & \text { References } & 66\end{array}$

CHAPTER FIVE - MARKET ANALYSIS

5.0

Introduction

68

5.1

Market Definition and Delineation

68

5.2

Market Overview

69

5.2 .1

Population Trends

70

5.2 .2

Median Age

71

5.2 .3

Median Household Income Trends

72

5.2 .4

5.3

Employment Trends

73

5.3 .1

Market Demand Analysis

75

5.3 .2

Resident Demand Analysis

76

Tourist Demand Analysis

78

5.3 .3

Student, Staff, Faculty and Alumni Demand Analysis

81

5.4

Market Demand Summary

82

5.5

Market Supply Analysis

83

5.6

Estimated Market Potential

86

5.7

Estimated Market Share

87

5.8

References

92

\section{CHAPTER SIX - FINANCIAL ASSESSMENT}

6.0

6.1

6.2

6.3

6.4

6.5

6.6
Introduction

Financial Objectives

Program Budget

Proforma Analysis

Proforma Conclusions

Project Financing

References
94

94

95

100

107

111

113 
CHAPTER SEVEN - CONCLUSIONS

7.0

7.1

7.2

7.3

7.4
Introduction

Summary of Key Findings

Final Recommendation

Ancillary Benefits

Issues for Future Consideration and Study
115

115

122

123

124 


\section{LIST OF TABLES}

$\begin{array}{lll}5.1 & \text { Population Trends } & \mathbf{P a}\end{array}$

$\begin{array}{lll}5.2 & \text { Median Age Trends } & 71\end{array}$

$\begin{array}{lll}\text { 5.3 Median Household Income Trends } & 72\end{array}$

5.4 Nonagricultural \& Salaried Workers by Industry 74 in Rhode Island

$\begin{array}{lll}5.5 & \text { Resident Demand Analysis, } 1995 & 77\end{array}$

5.6A South County Tourism Demand Analysis, Low Estimate 79

5.6B South County Tourism Demand Analysis, High Estimate 79

$\begin{array}{lll}5.7 & \text { Newport County Tourist Demand Analysis } & 80\end{array}$

5.8 URI Student, Staff, Faculty, \& Alumni Demand Analysis 82

5.9 Market Area Demand Summary, $1995 \quad 83$

$\begin{array}{lll}5.10 & \text { Inventory of Existing and Planned Market }\end{array}$

$\begin{array}{lll}5.11 & \text { Estimated Market Potential } & 87\end{array}$

$\begin{array}{lll}\text { 5.12A } & \text { Market Share Estimate, Best Case Scenario } & 89\end{array}$

5.12B Market Share Estimate, Worst Case Scenario 91

$\begin{array}{lll}6.1 & \text { Program Budget } & 96\end{array}$

$\begin{array}{llr}6.2 & \text { Cost Per Hole Budget Figures } & 98\end{array}$

$\begin{array}{lll}\text { 6.3A Projected Rounds Mix and Fee Schedule, } & 102\end{array}$

Worst Case Scenario

$\begin{array}{lll}\text { 6.3B Projected Rounds Mix and Fee Schedule, } & 103\end{array}$

Best Case Scenario

$\begin{array}{lll}\text { 6.4A Proforma Projections, Worst Case Scenario } & 106\end{array}$

$\begin{array}{lll}\text { 6.4B Proforma Projections, Best Case Scenario } & 107\end{array}$

$\begin{array}{lll}6.5 & \text { Proforma Projections, Mid-Range Estimate } & 110\end{array}$ 


\section{LIST OF FIGURES}

1.1A Preliminary Concept Plan (PCP), Front Nine Holes

1.1B Preliminary Concept Plan (PCP), Back Nine Holes

3.2 Proposed Site Location

4.1A Soils Analysis, Front Nine Holes 49

4.1B Soils Analysis, Back Nine Holes $\quad 50$

4.2 Site Access Map 56

4.3 Site Sketch, URI Disposal Area and 59

4.4 Superfund Remediation Process Timeline 62

$5.1 \quad$ R.I. and U.S. Annual Employment Rates, 73 1980 to 1995 
CHAPTER ONE - INTRODUCTION 


\subsection{Introduction and Project Overview}

The University of Rhode Island is planning to design and construct a low input, low impact, public golf course, research, and teaching facility (hereafter referred to as the "proposed golf course") on the northwest quadrant of the Kingston Campus. The proposed 230-acre site includes agricultural land, upland forest, a gravel bank, and an abandoned landfill, currently designated by Environmental Protection Agency (EPA) as a Superfund site (Devine and Casagrande, 1994). The golf course is currently in the planning and conceptual design phase and the project team recently received approval from key URI administrators to pursue the project further. No hard cost estimates have been prepared, but the preliminary budgets place the cost of the project in the $\$ 3$ to $\$ 4$ million range.

The project is being proposed by a multi-disciplinary team from the College of Resource Development which has a long history of turfgrass research and dynamic new programs in landscape architecture, ecological restoration, ecosystem management (Devine and Casagrande, 1994). The project team includes Barry Devine, a $\mathrm{PhD}$ candidate with an MS in plant ecology, and experience in designing several golf courses. Drs. Noel Jackson a turfgrass pathologist, W.M. Sullivan an agronomist, R.A. Casagrande an entomologist, P. August a resource ecologist, and A. Gold a hydrologist.

The design of this course will demonstrate, evaluate and add to the current state-of-the-art knowledge regarding low maintenance course design and restoration ecology. This design will minimize dependence on inputs of pesticide, water, 
nutrients and labor, while incorporating measures to protect and improve water quality, preserve and enhance wildlife habitat, promote open space, and provide a unique educational and research experience (Devine and Casagrande, 1994).

\subsubsection{Project Objectives}

The overall objective of this project is to design and construct a low input golf course that focuses on environmentally appropriate design and management measures while meeting the demands of the golf community. Moreover, this facility is to serve as an important teaching and research asset for URI. Specific objectives include the following (Devine and Casagrande, 1994).

a. To establish a set of written guidelines for a low-input golf course. The guidelines should have wide applicability for construction of new courses and renovation of older ones.

b. To meet a local need for additional golf and recreational facilities for URI and surrounding communities with a course that will appeal to golfers of all abilities.

c. To construct a Demonstration/Teaching facility to be used by URI students, faculty, researchers, golf course superintendents and others in the golf industry. This will allow instructional programs in low maintenance golf course construction and management, wetlands restoration, low impact course design utilizing GIS and CAD software, low maintenance turfgrass and groundcovers, landfill remediation, and other related fields.

d. To develop a research facility with opportunities to investigate pest management techniques, evaluation of grasses and groundcovers, and landfill remediation in a multi-disciplinary approach, on a working golf course.

e. To assist the State in taking a lead role in the cleanup and site remediation of the EPA designated Superfund Site/URI Disposal Area, participate in the development of the EPA required remedial investigation and feasibility studies, and incorporate these activities and guidelines into the project. 
f. To provide an excellent golf teaching and practice facility for use by URI teams and physical education classes, recreational programs, University functions, and community programs.

g. To build a financial asset for the URI capable of generating income for University programs.

\subsubsection{Project Layout and Key Features}

Figures 1.1A and 1.1B are a preliminary concept plan (PCP) for the proposed project which were prepared by one of the projects key proponents, Barry Devine. In addition to the 18-hole golf course, the project will also incorporate a target range, putting course, a three hole research and demonstration site, a nature walk, a research and teaching lab, maintenance buildings, and clubhouse facilities. The following narrative, prepared by Devine and Casagrande (1994), provides a brief overview of the key features of the proposed course.

The 18-hole golf course will be approximately 6900 yards when played from the tournament tee's with 2 par 3's, 5 par 4's, and 2 par 5's on both the front and back holes. However, through an innovative design utilizing multiple tees at vary distances and shot angles, the course can also be played as a par3/par4 approach length course approximately 4,000 yards for those without the time or talent to play the full length course. The course may be scheduled for executive-length play at certain times of the week. An extra 3 holes will be developed in the quarry/landfill site to serve research/demonstration needs and to serve as a backup, allowing rerouting of the course if any of the other 18 holes must be removed from play for research or maintenance purposes. Located adjacent to the target range, these holes might also serve as a mini course for instructional and/or recreational purposes. 
Greens, and tees will be above-average size to accommodate reducedmaintenance velvet bentgrass and provide for multiple pin and tee placements. These areas will require far less fertilizer and irrigation than comparable courses, but will be maintained to the highest standards. Several of the greens complexes will be newly designed, and others will be modeled after some of the world's classic golf holes (and will be so-identified). The course will feature "island fairways" which provide a real shotmaking challenge. Through the use of endophyte-protected fine fescues and other low maintenance grasses, most of the fairway areas will be maintained to standards that are average for this area, but with far less maintenance. An exception will be designed-in landing areas which will manicure, encouraging golfers to play those areas. Roughs will be extensive, naturalized, and will receive very little maintenance, except as needed to mitigate risk of Lyme disease.

The front 9 (agriculture land) will be a links course, built in the tradition of this design. Rolling mounds, fairway bunkers and variable height fescue roughs will highlight this area. The back 9 (upland forest) will be a parkland-type course with rolling fairways threading through oak and maple woodlands, offering a complement of natural hazards and existing vegetation.

The design will avoid protected wetland areas and provide substantial buffers around these sites. Disturbed areas will be naturalized and ecologically rehabilitated through the use of different landscape models including meadow, wetland, woodland, and ponds. A walking trail will offer an additional educational and recreational experience distinct from the golf course.

The target range plan calls for a limited distance practice range of 30-40 elevated tee stations. Players will hit to a mosaic of nine true greens intersperse with 
strategic traps and shallow ponds at distances from 30-250 yards. Accurate yardage to the center of each green will be displayed at each tee station. The tee stations will feature real turf, high quality mats, uphill and downhill lies, and a few sand traps. Players, from beginners to experts can get valuable practice hitting buckets of balls to greens or when scheduled, playing a round on the range. At each green, a simple cup mechanism will announce a hole in one, a challenge that appeals to players of all skills levels.

The target range will be small, occupying about 5 acres, quick and inexpensive to build, and easy to operate. The greens will be for target use only, simple to construct and maintain. A 9-18 hole scoring system can be used for scoring a round on the range, depending on where the shot comes to rest. This target facility provides the opportunity to establish leagues and offer teaching and instructions.

A 9-18 hole putting course is planned as an integral component of this project. From a golfing a perspective, more than half of the shots in a round of golf are putts, and most gofers can benefit greatly from the practice on true greens. From the perspective of a golf course manager, greens represent, by far the most serious management problems on a course. A series of greens established in different types of bentgrasses with varying mowing and management regimes, will offer unparalleled research and educational opportunities.

Holes will be 20 yards or less from the drop area and built as rolling and undulating mounds, slopes and flats, bordered by sand traps, water, and landscape plantings. It will allow practice on real surfaces under bentgrass cultivar and mowing height, showing golfers why they play "fast", "slow", or in between. 


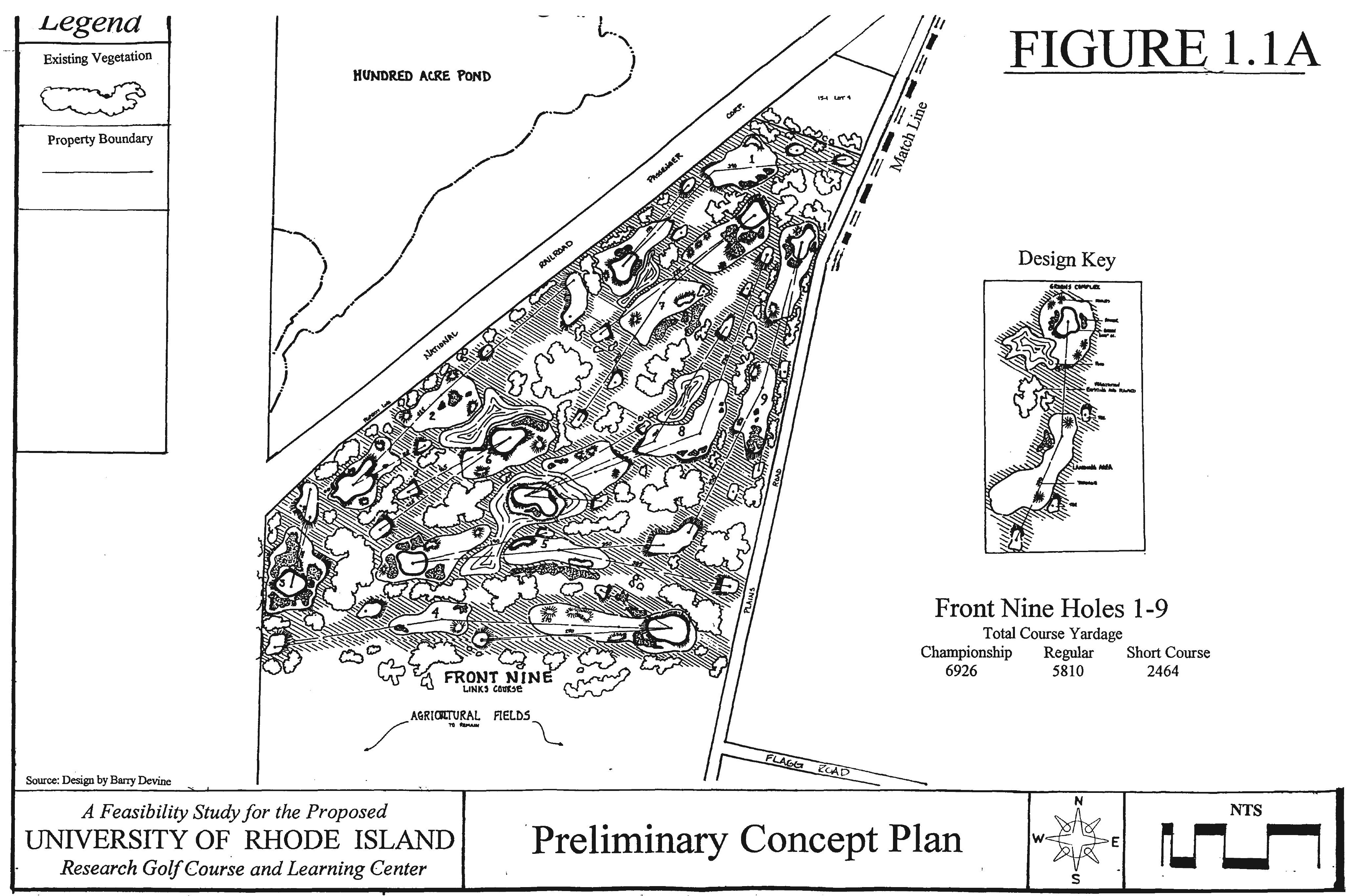




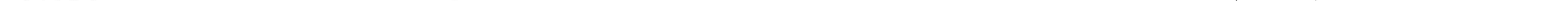




\subsection{Purpose/Objectives of the Feasibility Study}

The primary purpose of this feasibility study is to evaluate the proposed projects overall chance of success. In simplest terms, the feasibility study seeks to answer the fundamental real estate question, "Will the project work?" (Hanford, 1972). To answer this question, the study will focus on three specific objectives:

Objective \#1: $\quad$ To conduct a site inventory and analysis of the proposed project site in order to identify any natural or manmade physical constraints which could adversely affect the project.

Objective \#2: $\quad$ To conduct a market analysis in order to evaluate the market demand for a new golf course within the project's market area.

Objective \#3: $\quad$ To conduct a financial assessment of the proposed project which evaluates development costs, operating expenses, and projected revenues to determine whether the project can be a profitable venture for the University.

\subsection{Significance of the Feasibility Study}

It is anticipated that the results of the feasibility study will be significant for the following reasons:

a. The analysis contained in the study can be used to educate key University administrators regarding the degree of risk associated with developing a multi-million dollar project of this type.

b. The findings of the study can assist University administrators with the "build" or "no build" decision which is required at the end of the planning and conceptual design phase.

c. The findings can be used as a tool to gain support from financial partners, lenders, and the public sector. This assumes that the findings will support the notion that the golf course should be built. 
d. The research, analysis and findings can be used by the project's proponents to educate the University's faculty and student regarding the benefits of the proposed gold course.

\subsection{Methodology/Approach}

The following methodology will be utilized to accomplish the three objectives of the feasibility study.

\subsubsection{Objective \#1 - Site Inventory and Analysis}

"an inventory of existing and physical site conditions and characteristics followed by an analysis of these physical conditions and characteristics to determine constraints and suitability of the site for the golf course development" (Muirhead and Rando, 1994).

The first task under this objective will be an environmental inventory and analysis of the proposed site using the McHarg overlay technique. The inventory will be conducted using the following categories and criteria:

a. Topography A map using 30 foot intervals will be developed to identify constraints due to excessive slope (15-20 percent) and extreme flatness ( $0-2$ percent).

b. Surface and Ground Water

All water bodies (ie. streams, ponds, rivers, lakes etc.) will be identified and categorized. All watershed boundaries, aquifer recharge areas and well head protection zones will be delineated. These features will be reviewed relative to the projects irrigation needs and potential pollution concerns.

c. $\underline{\text { Soils }}$

A soils analysis will be conducted using the USDA Soil Survey of Rhode Island in order to identify those soils which are not suitable for golf course development. In particular, this section will focus on identifying soils with poor drainage characteristics and high rock or ledge content. 
d. Vegetation

A vegetation analysis will be performed using field research and Kuppa and McConnel Maps (1972). Particular attention will be paid to delineating any existing wetland areas.

The second task will be to analyze and compile the results of the environmental inventory into a constraints map. This map will summarize those site conditions which constrain the development of the proposed golf course. Next, the constraints map will be compared to the preliminary concept plan (reference Figure 1.1A \& B) to identify any areas which need to be redesigned to help mitigate adverse environmental impacts and design, permitting and construction problems.

The third task will be an inventory of the existing manmade site constraints which will include the following categories:

a. Utilities and Services

The location of gas, water, sewer and electric utilities will be identified and mapped.

b. Circulation and Access

A map will be developed showing the following: proposed site access points and the sites relationship to major roads. The primary circulation patterns within the site will also be analyzed.

c. URI Disposal Area

This section will summarize the findings of the EPA Final Listing Inspection Report (FLR) from March 1990.

The last task under this objective will be to identify and assess the potential impact of FLR findings on the project's cost, schedule, design and construction. It is anticipated that some case study research of existing golf courses will be required. 


\subsubsection{Objective \#2 - Market Analysis}

"A process by which the demand for and supply of a particular project is determined based on demographic information about the character of a community within a specified market area" (Muirhead and Rando, 1994).

The first task in this section will be the geographic delineation of the primary and secondary market areas for the proposed project. The typical distance for these two market areas are 10 and 20 miles, respectively (Muirhead and Rando, 1994). The National Golf Foundation (NGF)(1989) further defines the primary market "as the area for which most golfers would be happy to travel if they could play every day". The secondary market would be "that area from which golfers would be willing to travel if necessary to play golf regularly" (NGF, 1989). It is anticipated that the boundaries of the two market areas will have to be adjusted slightly in order to match the appropriate census areas.

The second task will be a market overview which will provide the reader with general background information on the economic vitality of the market area. This will be accomplished by reviewing key economic and demographic indicators such as population changes, median age and income characteristics, and employment trends.

The third task will be to evaluate the market demand for a new golf course using techniques and statistics developed by the NGF. For the sake of clarity the potential customers for the proposed golf course will be divided into three categories: permanent residents, tourists, and URI students, staff, and faculty and alumni. It is anticipated that certain key assumptions will have to be made regarding the URI student population and the influx of seasonal tourists during the summers months. 
The fourth task will be a market supply analysis which will establish the existing golf course capacity within the market area. This will be estimated by performing a detailed inventory of all existing and planned courses within the market area. The market inventory will cover all public golf courses and will include the following elements: total number of courses, the location, course designer, estimated number of annual rounds, green fees rates, the regulation play yardage, par and slope rating, and a maintenance rating. These variables will provide a clear picture of the cost, course quality, and demand patterns of the existing competition.

The fifth task will be to establish an estimated market potential for the proposed project's market area. This is calculated by subtracting the market supply and demand figures. The resulting figure will determine whether there is any unmet market demand within the market area. The final task will be a market share analysis which will establish capture rate for the proposed golf course. It is anticipated that the market share estimate will be in the form of a high and low range.

\subsubsection{Objective \#3 - Financial Assessment}

"Determines the potential financial retum a proposed project can obtain. Also provides the developer, financial partners or investors, and lenders with an estimate of the risks and rewards of a proposed venture" (Muirhead and Rando, 1994).

The first task under this objective will be to interview key project proponents and University administrators in order to establish the financial objectives for the proposed project. The second task will be to develop a program budget for the 
proposed project. This program budget will include the costs to plan, design, permit, construct and equip the proposed golf course.

The third task will be a proforma analysis which evaluates the development costs, operating expenses, and projected revenues for the proposed golf course to determine whether the course can be a profitable venture for the University. All these figures will be projections (or estimates) based on the historical data contained in the NGF literature, a preliminary budget developed by Devine and Casagrande, and my professional training in construction management and planning.

The task of identifying a source(s) of capital for the proposed project has been accomplished; thus, the research associated with project financing which is a typical element of most feasibility studies will not be required. The University proposes to use the Rhode Island Industrial and Recreational Building Authority which raises capital through the sale of bonds. A brief overview of this financing tool and specific structure of the bond issue will be provided.

\subsection{Limitations of the study}

The author makes the following limitations regarding the purpose and content of the feasibility study:

a. The site inventory and analysis conducted in Chapter Four is designed to compile the environmental constraints to golf course development. This section is not designed to evaluate and project the impacts of the golf course on the proposed site.

b. To date no map in the appropriate scale has been found for the agricultural field west of Plains Road. Thus, the site analysis per- 
formed in Chapter Four may have to be limited to those portions of the proposed site which are east of Plains Road only.

c. This study will not evaluate the suitability of the proposed site relative to other University land holdings.

d. The success of the "inventory of existing facilities" conducted in Chapter Five was highly contingent on the willingness of other golf course owners and managers to share information which is proprietary in nature. A NGF market study was made available to the author by Mr. James Kirby from the Newport National Golf Club. In some cases it also became necessary to make projections using NGF generalized industry statistics.

e. The proposed golf course has an important academic and research focus which is inherently important to the University's mission as a land grant institution. Trying to quantify the value of the educational element of this project is beyond the scope of the is study. No allowance will be made for this element in the financial feasibility analysis found in Chapter Six. 


\subsection{References}

Devine, Barry and R.A. Casagrande. The University of Rhode Island College of Resource Development Research Golf Course and Learning Center: A Project Overview. November, 1994.

Handford, Lloyd. Feasibility Study Guidelines. The Institute of Real Estate Management. Chicago. 1972.

Muirhead Desmond and Guy Rando. Golf Course Development and Real Estate. The Urban Land Institute. Washington, DC. 1994. 
CHAPTER TWO - PROFILE OF THE UNIVERSITY OF RHODE ISLAND 


\subsection{Introduction}

The purpose of this chapter is to provide an overview of URI's history and development, in order to familiarize the reader with the University's roots as a land grant, agriculturally based research institution. Included in this historical overview will be a summary of the University's mission, underlying principles and goals, which will serve as a foundation for evaluating the merits of developing a teaching and research oriented golf course. This analysis is divided into four time periods: The early years, 1892-1945; The Post War Years, 1945-75; Recent Trends, 1975 - 1991; The Carother's Administration, 1991 - Present. The chapter will close with a summary of the key findings.

\subsection{The Early Years, 1892 - 1945}

The University of Rhode Island, like other land grant institutions throughout the United States, was established and funded under two Federal Acts. The first was the Morrill Act of 1862, which was a bill introduced to the United States Congress by Justin Morrill of Vermont. According to URI historian Herman Eschenbacher (1967) the Morrill Act:

"provided for a grant of 30,000 acres of public land to be awarded to the individual states for each Representative and Senator in the national legislator .... to be used by the state to endow at least one college where the leading objective should be, without excluding other scientific and classical studies, and including military tactics, to teach such branches of learning as are related to agricultural and the mechanic arts."

The legislation also provided land grant institutions with their three basic objectives: teaching, research and community service (URI, 1982). 
After considerable debate and controversy the Rhode Island legislature selected Brown University as the recipient of the Morrill Grant. In 1863, Brown University established an Agricultural Department which was designed to fulfill the Morrill Act's basic goals and objectives. From the onset Brown University's agricultural program was poorly received by the state's rural farming communities who questioned the program's inaccessible urban location, the curriculum, the lack of financial aid, and low acceptance rate for farm children.

The Federal Government became aware of the inadequacies within the Morrill Act as exemplified in Rhode Island and passed a second Federal law in.1887, known as the Hatch Act. Under this measure, $\$ 15,000$ a year was to be granted to each of the states for the establishment of an agricultural experiment station (Fouratt, 1971). A legislative committee was established in June 1888 by Governor Royal Taft and charged with finding:

"a tract of land that was readily accessible to the farmers and one which would embrace as many varieties and qualities of soil as possible in order that experiments could be carried out under diverse conditions" (Eschenbacher, 1967).

After careful deliberation, the search committee settled on the 140 acre Oliver Watson-Tefft Farm which was located just north of the village of Kingston. The farm was purchased on September 27,1888 for $\$ 1,000$. A dormitory, laboratory and road connecting the station to the village were quickly established (Eschenbacher, 1967).

In May 1892, the Rhode Island legislature enacted the Davis Bill, which incorporated the existing "Board of Managers" and officially charged them with running the experiment station, and the newly promulgated "Rhode Island College 
of Agriculture and Mechanic Arts" (hereafter the "College") (Eschenbacher,1967). Under this statute the College also became the new recipient for the Morrill grant and other state capital and operating funds.

The wording of the Davis Bill, while heavily influenced by the Morrill and Hatch Acts, provided valuable insight into the Rhode Island legislature's rational for establishing the College. The leading objective of the College according to this bill should be:

"without excluding other scientific and classical studies, and including military tactics, to teach such branches of learning as are related to the agriculture and the industrial classes in the several pursuits and professions of life,..." (Eschenbacher, 1967).

According to Eschenbacher (1967) the target population for the College was the children of Rhode Island's working class farmers and factory workers, who lacked the academic credentials and money to attend the state's only other institution, Brown University.

It is also clear from the writings of President Washburn, the College's first President, that the primary goal of the College was service to the needs of the state. This is clearly reflected in the early curriculum which was designed to

"instruct youth in the highly specialized competencies required by the State's farms and industries, a curriculum not as narrow as a trade school, but not as ambiguous as a liberal course of studies" (Eschenbacher, 1967).

This tradition of applied learning and service to the state continued under Washburn's successor, Kenyon Butterfield who vigorously expanded the College's Extension Services. These outreach programs offered short courses, lectures and technical assistance in animal husbandry and farming. Moreover, faculty and student 
research was geared towards the specialized needs of Rhode Island's industries and farms.

The new state College had a modest beginning, enrolling only 21 freshmen students in September, 1892 (Fouratt, 1971). From its inception, funding at the College was tenuous and "as early as 1900 pressure from the press and general assembly caused the Board of Managers to ponder means of changing the faculty with a view to further reducing expenses (Eschenbacher, 1967).

The first curriculum had two bachelor of science degrees: one in agriculture and one in mechanics (Coutu, 1995). The curriculum constantly changed and expanded over time. By 1932 the College boasted Schools of Agriculture, Engineering, Home Economics, Science and Business Administration. The College's growth was slow, but relatively constant (except for the depression years) with enrollment reaching 940 students in 1932, and 1,216 students in 1940 (Fouratt, 1971).

During the period of 1941 to 1944 , enrollment dropped dramatically from 1131 to 363 students as America prepared for World War II. The College's curriculum was also overhauled in response to the country's war time needs with a greater emphasis being placed on the mechanical sciences (Eschenbacher, 1967).

\subsection{The Post War Years, 1945-75}

According to Eschenbacher (1967) the essential impulses of American society were altered by the war and "college-going emerged from a condition of vogue to one of necessity in the post war years". Under the auspices of the G.I. Bill, enrollment 
at the College increased 85 percent from 1945 to 1948 reaching 2,215 students. The post war boom at the College peaked in 1951 at 3,736 students.

Under the careful stewardship of President Woodward (1941-1958) a new aggressive faculty was recruited with a wider span of interest, the curriculum was reshaped with a greater emphasis on the mechanical sciences and liberal arts, the College expanded its graduate and extension programs, night courses were added at the University's Providence campus and the College achieved University status in 1951. Woodward's tenure, like those of his predecessors, was also marked by severe funding problems as the University struggled to expand and update its facilities.

After 17 years of conservative leadership under Woodward, the University came under the stewardship of a series of more controversial and progressive leaders. The tenures of Presidents Horn (1958-67) and Baum (1968-73) marked a departure from the University's agriculturally-oriented administrators and emphasized expansion of the liberal arts and science programs (Eschenbacher, 1967). By 1962, total student enrollment had increased to 6,500 and the University had become a major research institution with six doctoral and 33 master's degree programs (URI, 1982). Funding for all capital projects and operating revenues was always tenuous and the University still relied heavily on the largess of an unpredictable state legislature for 50 percent of its total annual income. Other highlights from this period include: the unionization of the faculty, URI was named one of four sea grant universities in the country, and the Faculty Senate as well as the Alton Jones campus were established (Registry of the Papers, 1969 and 1975). 


\subsection{Recent Trends, 1975 - 1991}

The post-industrial era brought URI a whole new set of issues and challenges. In Rhode Island, the manufacturing, textiles and agricultural jobs were replaced by jobs in service, information, defense and jewelry based industries. These new jobs required high-tech skills in fields such as computer science, engineering and finance. In response to this demand, the University under the leadership of Presidents Newman (1974-83) and Eddy (1983-91), began to rethink the curriculum. A whole range of new programs emerged, many at the graduate and doctoral level, including biochemistry, computer science, marine affairs, ocean engineering and computer engineering (URI, 1982). Extension and research centers in areas such as robotics, small business development, community planning, education, energy, transportation and coastal resources were also developed.

Enrollment during this period increased gradually from 14,451 in 1977 to 15,395 students in 1991 (URI, 1982). Newman, who came to the Presidency with mostly private sector experience, also spent considerable time streamlining the budget process and operational procedures "to better cope with the impending realty of reduced state aid" (Registry of the Papers, 1985). Newman's prediction was realized in the later part of the Eddy Presidency when the state appropriation in FY 1989-90 was level, and FY 1990-91 was reduced 9.8 percent (Lawrence, 1992). 


\subsection{The Carothers Administration, 1991 - Present}

From the beginning of its tenure in July, 1991, the Carothers administration has been surrounded by a great deal of tumult and controversy. Much of this controversy stems from the University's perennial funding problems which have become particularly acute since 1991 . Severe reductions in state funding, particularly during the Sundlun administration, have reduced state aid to 30 percent of the University's budget (McVicar, 1995).

To compensate for these reductions the University has raised tuition approximately 75 percent since 1989, an action which many faculty now feel has contributed to the recent decline in student enrollment (McVicar, 1995). The other byproducts of these budget shortfalls have been a series of stop-gap cuts in staff and reductions in service which failed to solve what many experts feel is a long term, structural deficit in the University's revenue stream. The fiscal problems culminated on May 19, 1995 when Carothers announced wholesale reductions of 100 positions and 25 percent of the University's programs. These reductions, while necessary for the long term fiscal health of the University, have created additional animosity and mistrust between the faculty and the Carother's administration.

The second source of contention under the Carother's administration was a five year strategic plan designed to dramatically change the current curriculum. According to the University Pacer (1993) this plan has three major elements:

1. A new multi-disciplinary, goals centered general education program called the "Quadrangle Concept". 
2. The formation of eight "learning partnerships" to enhance the growth of students through applied and collaborative learning projects which combine faculty, staff, private business, government and labor.

3. The use of work portfolios to show student growth and success in writing, math and communication.

An integral part of this proposal is the understanding that the University can no longer rely on the largess of the state for its financial needs. The University must look to generate new sources of revenue through partnerships with private business, private and federal grants, and other creative, nontraditional sources.

The faculty's reaction to the five year plan has varied from "cautiously optimistic" to "openly skeptical" (Pacer, 1993). Thus far, they have failed to maintain the President's timetable and numerous concerns and questions have been raised regarding the academic, administrative and financial implications of the proposal.

\subsection{Summary of Findings}

This brief synopsis of the University's history has demonstrated that certain trends have remained consistent throughout University's evolution. First, the three fundamental postulates of a land grant institution (teaching, research, and service), although heavily modified by technological and social changes, are still the foundation of the University's mission. These principles have provided the University with a sense of continuity and stability throughout its first 100 years, and will continue to guide it in the future (URI, 1982).

Second, the University from its inception in 1892 , has historically experienced financial problems which has adversely affected its ability to become a first rate 
academic and esearch institution. This trend will mostly likely continue unless the University creates new revenue sources outside of state aid and tuition.

Third, the objectives of the proposed project as outlined by Devine and Casagrande (1994) are consistent with both the Carother's five-year strategic plan and the University's mission as a land grant institution. Finally, given the current state of the University, it is reasonable to assume that the proposed project will be highly controversial. How the project is introduced to organizations such as the Faculty Senate will require careful planning and political courage on the part of the Carother's administration. 


\subsection{References}

Eschenbacher, Herman. 1967. The University of Rhode Island. New York. AppletonCentury-Crofts.

University of Rhode Island (URI). 1982. The Edge of Excellence: The New State University and the Economic Development of Rhode Island. Kingston, RI.

Fouratt, Mathew. 1971. Campus Circulation Problems: A Study of motor Vehicle Congestion at the University of Rhode Island. Kingston, RI.

Coutu, Aaron. 1995. The University of Rhode Island: Laying the Foundation. Awakenings. March, 1995. Volume 3: Issue 3.

Registry of the Papers. 1969. The Working Papers of President Francis H. Horn. Kingston, RI. University of Rhode Island Library: Office of the Special Collections.

Registry of the Papers. 1975. The Working Papers of President Werner A. Baum. Kingston, RI. University of Rhode Island Library: Office of the Special Collections.

Registry of the Papers. 1985. The Working Papers of President Frank Newman. Kingston, RI. University of Rhode Island Library: Office of the Special Collections.

Lawrence Judith. 1992. Fact Book 1990-91. Kingston, RI. University of Rhode Island: Office of Institutional Research.

McVicar, Morgan. Carothers at the Crossroads. Providence Journal-Bulletin. May 19, 1995.

University of Rhode Island. President Carothers announces 5-year strategic plan. The University Pacer. September 23, 1993. 
CHAPTER THREE - SITE DELINEATION AND REGULATORY REVIEW 


\subsection{Introduction}

The task of selecting and acquiring a site for the proposed golf course has already been accomplished; thus, the site selection process which is an element of a feasibility study will not be required. Instead, this chapter will first identify and delineate the proposed site through the use of locus maps and a narrative description. Second, the chapter will identify and examine any federal, state, and local regulatory requirements and issues which potentially may affect the project. Finally, the chapter will close with a summary of the key findings.

\subsection{Site Delineation}

The proposed golf course location is within the Kingston Campus of URI, in South Kingston, RI. Figure 3.1 provides a regional perspective on the location of Rhode Island, South Kingstown, and the Kingston Campus, which is 30 miles south of Providence, approximately 75 miles south of Boston, 160 miles north of New York City and six miles west of Narragansett Bay. The proposed site for the golf course is located within the northwest quadrant of the 1,248-acre Kingston Campus and is roughly bounded by private, undeveloped land to the south, private undeveloped land and residential homes to the north, North Road to the east, and the National Railroad Passenger Corporation (or Northeast Corridor) right-of-way to the west. Plains Road bisects the proposed site acting as an edge, or boundary, between two sub-parcels with distinctly different characteristics. Figure 3.2 shows the University's total land holdings at the Kingston Campus and the approximate location of the proposed site. 

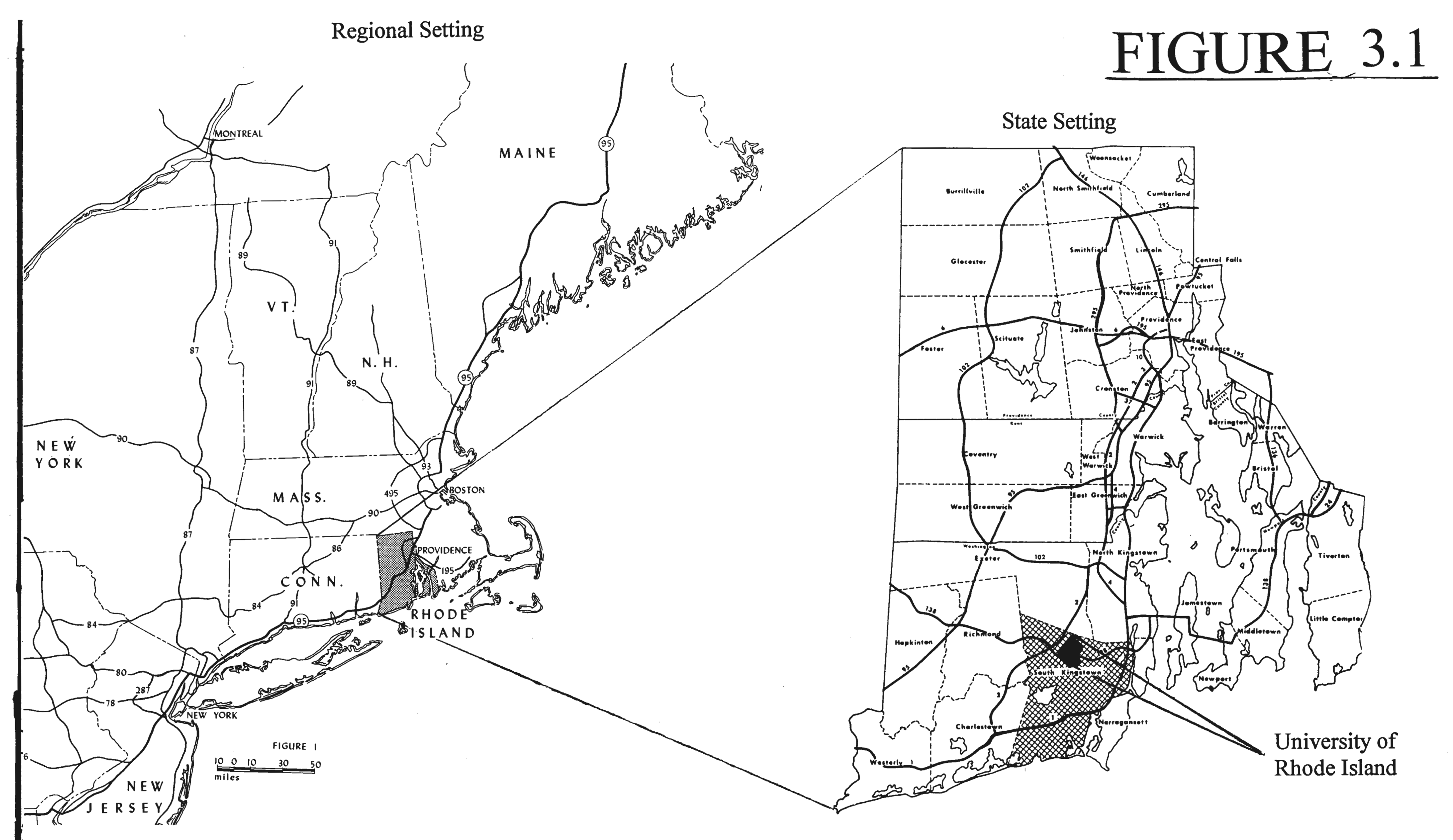

Source: South Kingstown Comprehensive Plan

\begin{tabular}{c}
$\begin{array}{c}\text { A Feasibility Study for the Proposed } \\
\text { UNIVERSITY OF RHODE ISLAND } \\
\text { Research Golf Course and Learning Center }\end{array}$ \\
\hline
\end{tabular}




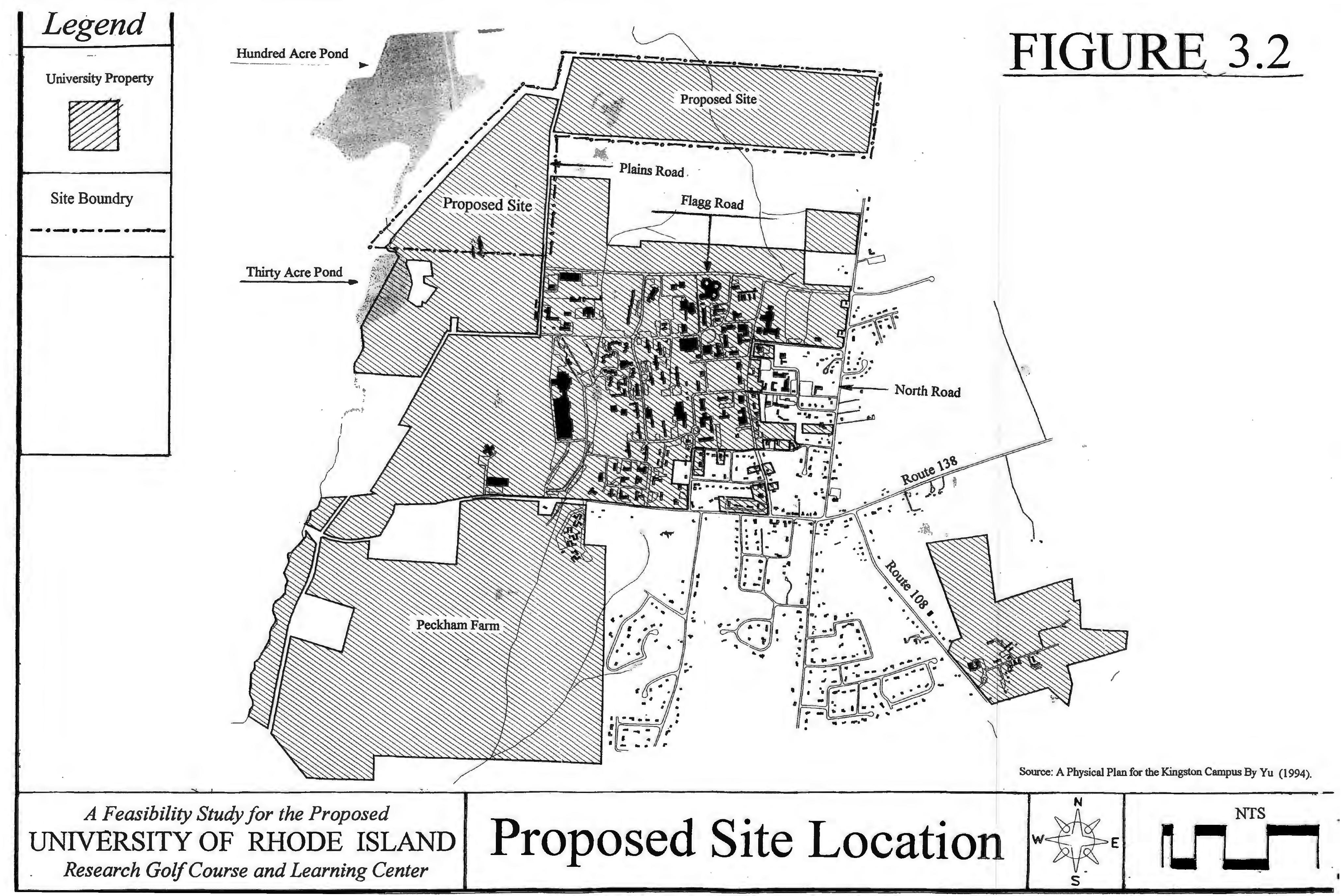




\subsection{Site Description}

The proposed site is approximately 230 acres in size and encompasses an extremely diversified mix of existing land uses including agricultural fields, upland forest, a sand and gravel pit, and an abandoned solid waste landfill. According to project proponents a primary consideration in centering the course around the URI Disposal Area (instead of at the Peckham Farm on Route 138) is the availability of three distinct ecosystems (Devine and Casagrande, 1994). These three distinct ecosystems will make the course visually interesting and physically challenging for the course designers, URI researchers, and players.

The largest of these ecosystems is the 150-acre agricultural fields which are bordered by Plains Road to the east and the National Railroad Passenger Corporation right-of-way on the west. The parcel is pyramid shaped with the long axis running in a north-south direction which is the preferred solar orientation for golf course development (NGF, 1989). This area is relatively level and uniform with limited shrub and tree coverage and low plant diversity, which is a byproduct of its most recent use as agricultural land for vegetable produce and turfgrass production.

The second major ecosystem is the 60 -acre upland site, with stone fences and a mixture of open grassy areas, shrubs, and forest, which is typical for much of Rhode Island's overgrown pasture land (Devine and Casagrande, 1994). This parcel is rectangular shaped (which is ideal), but the long axis is along an east-west alignment which is not the preferred solar orientation for golf course development (NGF, 1989). The parcel has a series of gradual grade changes and "tables" which make the terrain 
more dynamic than the agricultural fields. The parcel is divided in half by a substantial wetland area (approximately 10-12 acres in size) which runs on a northsouth axis, and a logging trail which runs on an east-west axis.

The final ecosystem is the 17 acre sand and gravel excavation site which is bordered by the Plains Road to the west, the uplands forest area to the east, and the closed West Kingston Town Dump to the south. Approximately 12 acres of the gravel bank, commonly known as the URI Disposal Site, has been filled with URI debris and capped with gravel. There are also are a number of rock outcroppings, mounds, gravel banks, wetland areas, and small ponds which are all a byproduct of the excavation process (Devine and Casagrande, 1994). Both the URI Disposal Site and the former West Kingston Town Dump are active EPA Superfund sites.

\subsection{Regulatory Requirements and Issues}

According to Muirhead and Rando (1994) one of the most significant trends in the golf course development industry has been the growing public awareness regarding environmental issues. This growing public support has translated into strict regulatory requirements and restrictions, and complex permitting procedures which make golf course development a daunting and risky venture. A recent case study publication published by the NGF, Lessons Learned From New Municipal Golf Course Development (1992) suggests a four to six year development process is fairly common for most golf courses. 
While not all of this time is attributable to regulatory requirements; the permitting process is a crucial step which can easily undermine a project if it is taken to lightly. The proponents of the URI golf course can expect to encounter the following federal, state and local agencies and regulations during the approval process.

\subsubsection{Federal Regulations}

\section{Army Corps of Civil Engineers (Corps)}

Clean Water Act, Section 404 - Under this federal act the Corps is given jurisdiction over the placement of fill in waters of the United States and their associated tributaries which includes wetlands. The basic objective of the program is to avoid, minimize, or mitigate the impact of projects on wetland areas and water bodies. The Corps delineates wetland area based on three criteria; soil, vegetation, and hydrology. They do not include buffer or perimeter wetlands in their definition.

If the project team's stated goal of "avoiding protected wetland areas and providing substantial buffers around them" (Devine and Casagrande, 1994) is realized, the project will most likely fall under the "Nationwide Permits Program" which has established thresholds for "limited actions". Typically a "Request for Jurisdictional Determination" would be filed with the Corps after RIDEM approvals are received. Assuming no complications, this process takes approximately three months to complete.

\section{Environmental Protection Agency (EPA)}

Comprehensive Environmental Response, Compensation, and Liability ACT (CERCLA) as amended by the Superfund Amendments and Reauthorization Act of 1986 (SARA) This act gives the EPA jurisdiction over hazardous waste sites (such as the URI Disposal Site) and creates a revolving "Superfund" to help fund the remediation process. Under SARA the EPA was given statutory guidance on many key policy issues, cleanup standards were clarified, new legal power to facilitate voluntary and mandatory settlements were incorporated, state, local and citizen participation was mandated, and a level of health related review was added. The implications of this topic will more thoroughly discussed in Chapter 4. 


\subsubsection{State Regulations}

\section{Rhode Island Department of Environmental Management (RIDEM)}

Rhode Island Freshwater Wetlands Act - This act gives RIDEM, Wetlands Division, jurisdiction over all freshwater wetlands in the state these include bogs, marshs, swamps, ponds, and perimeter land within $50^{\prime}$ of said areas. Also under this jurisdiction's any river and riverbank area which is defined as land within $200^{\prime}$ of the edge of any flowing body of water having a width $10^{\prime}$ or more, and that area within 100 ' of the edge of any flowing body of water having a width of less than 10' during normal flow (FWWA, 1974). Any alteration within these areas, "or projects taking place outside freshwater wetlands which in all likelihood, due to their close proximity to wetlands or due to the size or nature of the project will result in alterations to the natural character of any freshwater wetland will require a permit" (FWWA, 1974).

Because of the magnitude of the proposed project and its proximity to freshwater wetland areas, it will most likely require a formal application process even if the design requires only "insignificant alterations" to wetland areas (Horbert, 1995). A formal review can take anywhere from six to nine months or longer if the site has complicated environmental issues.

Water Quality Certification (WQC) - This is a mandatory component of the formal application process, which is granted by the RIDEM, Division of Water Resources. This certification ensures that discharge from the proposed site will not harm water quality both within and around the site.

Rhode Island Pollution Discharge Elimination System Permit (RIPDES) - Because the site disruption will be greater than five acres, a RIPDES permit will be required. This permit reviews erosion and sedimentation controls for sheet-flow and point source storm water discharges during the construction period. The application and review process takes three to four weeks and typically is awarded without comment for those projects which have received a wetlands alteration permit (Wiegand, 1995).

This formal review process may also trigger either of the following: an endangered species review by the RIDEM, Natural Heritage Program, the Division of Fish, Wildlife, and Esturine Resources, and the U.S. Fish and Wildlife Service (Section 7, Endangered Species Act); a historical resources review by the Historical Preservation Commission (Section 106, National Historic Preservation Act) (Westcott, 1995).

\subsubsection{Local Regulations}

Town of South Kingston Zoning Ordinance (1994) - Under Article 11, Section 1100 a Public Zoning District was created which includes all federal, state and local properties. A strict reading of the ordinance would suggest that the Town of South 
Kingstown has no jurisdiction over the proposed site, except under the following circumstances:

a. If the University chooses to sell the proposed golf course to a private, for profit, developer or management company under Article 11,Section 1101 the land then falls under the Town's jurisdiction, and can not be developed until it is re-zoned by the Town Council.

b. A lease of the proposed golf course to a private, for profit, developer or management company is currently considered a "gray area" within the Town's ordinance. According to the Town Planner, South Kingstown would most likely seek a full zoning and site plan review (Lachowicz, 1995).

c. Under Rules 9.05, Paragraph B, Item 7 of the Fresh Water Wetlands Act (1974) the RIDEM must solicit public comment and approval from the city or town where the project is located. RIDEM may not issue a permit for a project which has been disapproved by a city or town council. This local "veto" power suggests that South Kingstown may have significantly more leverage during the permitting process than the zoning ordinance indicates.

The Town Planner declined however to identify what types of permitting requirements the project may face under these circumstances. He indicated that the proposed site resided in a "Ground Water Protection Zone" (Article 20) which could make it controversial with the general public. Moreover, he suggested that the project's water requirements needed to be reviewed relative to the existing capacity of the Chipuxet aquifer (Lachowicz, 1995).

\subsection{Summary of Findings}

This chapter has introduced the reader to the location of the proposed golf course and the general characteristics and features of the 230 acre site. The chapter reviewed the federal, state and local regulatory requirements that will impact the golf course development process. Case study analysis suggests that the permitting and approval phase will be a crucial step within the golf course development process 
which should not be taken lightly. It is highly likely that the project will face a formal, and lengthy, wetlands application process under RIDEM, and that the Town of South Kingstown will also have significant input into the review process. At the federal level the project will probably face only limited review by the Corps if the design goal of "no wetlands impacts" is maintained. 


\subsection{References}

Devine, Barry and R.A. Casagrande. The University of Rhode Island College of Resources Development Golf Course Educational and Research Facility: A Project Overview. Kingston, RI. August 3, 1994.

National Golf Foundation. 1989. Guidelines for Planning and Developing a Public Golf Course. Jupiter, Florida. National Golf Foundation.

Muirhead Desmond and Guy Rando. 1994. Golf Course Development and Real Estate. The Urban Land Institute. Washington, D.C.

National Golf Foundation. 1992. Lessons Learned From New Municipal Golf Course Developments Course. Jupiter, Florida. National Golf Foundation.

Environmental Law Institute. 1988. Superfund Deskbook: The Environmental Law Reporter. Washington, D.C.

State of Rhode Island and Providence Plantations, Department of Environmental Management, Division of Freshwater Wetlands. 1994. Rules and Regulations Governing the Administration and Enforcement of the Fresh Water Wetlands Act (FWWA ). Providence, RI. The Weil Publishing Co. Inc.

Personal Interview. Charles Horbert. Rhode Island Department of Environmental Management, Wetlands Division. May 25, 1995.

Personal Interview. Kim Wiegand. Rhode Island Department of Environmental Management, Division of Water Resources. May 25, 1995.

Personal Interview. David Westcott. Principle Planner, C.E. Maguire Group. May 25, 1995.

Town of South Kingstown. Zoning Ordinance. Adopted May, 24, 1994.

Personal Interview. Anthony W. Lachowicz. Director of Planning, Town of South Kingstown, RI. May 30, 1995. 
CHAPTER FOUR - SITE INVENTORY AND ANALYSIS 


\subsection{Introduction}

The purpose of this chapter is to conduct a site inventory and analysis of the proposed project site in order to identify any natural and manmade physical constraints to golf course development. The chapter begins with a summary of the pertinent findings for each of the four environmental inventory categories. This is followed by an overview of the key findings from the constraints map and preliminary concept plan (PCP) comparison.

Next, an inventory of manmade physical constraints will be performed to determine the status of the following categories: Utilities and Services, Circulation and Access, and the abandoned URI Disposal Area. The research regarding the URI Disposal Area involves a summary of the EPA Final Listing Report for the site. This is followed by a section which projects the potential impacts of the URI Disposal Area on the project's cost, schedule and design. Finally, the chapter will close with a summary of the key findings from this section.

\subsection{Environmental Inventory and Constraints Analysis}

An environmental inventory was performed on the proposed site, based on the following categories: Topography, Surface and Ground Water, Soils, and Vegetation. The significance of each category and the results of the inventory are as follows:

\subsubsection{Topography}

From the golf course architect's view point the topographic undulation (contour) of a site is the most important determining factor regarding the location 
of a golf course (Jones and Rando, 1974). In general terms, a gently rolling site is easier to develop, and more enjoyable to play, than a site with a steep, constant slope. Steep slopes are typically considered a constraint to golf course development for the following reasons: the cost of filling and grading large areas tends to be prohibitive; they create erosion problems during construction and maintenance; they can create tee to green "site line" problems which make play slow and affect safety; and finally, they tend to increase surface runoff problems if careful water management techniques are not used (Hawtree, 1983). For the purpose of this analysis "steep slopes" are defined as greater than 20 percent. (Slope is defined as the measurement of the amount land rises over a linear length and is usually given in a percentage format.)

According to Jones and Rando (1974) "extremely flat" sites also present a distinct set of problems for golf course development. First, a level site often has drainage or ponding problems because it does not shed water correctly, particularly during heavy rainfall. Second, level sites usually require inordinate amounts of fill to shape fairways and create tees, bunkers and greens, in order to make them visually interesting and challenging. For the purpose of this analysis "extremely flat" areas are defined as having slopes of zero to two percent.

A slope analysis of those portions of the proposed site which are east of Plains Road shows that, with the exception of excavation areas in the abandoned dump and gravel pit, no portion of the site was constrained by steep slopes. Beginning at North Road (Elev. $250^{\prime}+/-$ ) the eastern portion of the site slopes down to the wetlands 
area (Elev. $\left.170^{\prime}+/-\right)$ which bisects the site. The slope is very gradual, averaging roughly six percent over the $1,200^{\prime}$ foot interval. Moving west from the wetland area, the grade continues to slope gradually (three percent $+/-$ ) downward towards a series of small water bodies (Elev. 115') created by the gravel operation. Continuing west out of the gravel bank area, the grade raises gradually at a slope of approximately three percent to meet Plains Road (Elev. 135').

No slope analysis was performed on the agricultural fields because no map in the appropriate scale could be located. A field review however indicates that the agricultural fields are fairly level and probably fall into the "extremely flat" category referenced above. This suggests that this portion of the proposed site will require considerable filling and shaping to create features and avoid drainage and ponding problems.

\subsubsection{Surface and GroundWater}

According to Muirhead and Rando (1994), the availability of a cheap source of irrigation water is critical for a successful golf course development. Golf course water usage varies considerably based on course size, climatic conditions, soil types, grass type(s), and irrigation system. A typical golf in the northeast region course requires 300 to 500 gallons of water per minute or 432,000 to 720,000 gallons per day (gpd)(Moran, 1991). Irrigation water typically comes from one (or more) of the following sources: wells, streams, rivers, lakes, effluent or outright purchase from a local public source. The outright purchase is considered the least desirable option 
and can become a critical element to consider when determining the feasibility of a project (Jones and Rando, 1974).

The proposed site has a number of freshwater surface features which are located within or adjacent to the parcel and are potential sources of irrigation water. The agricultural field is located adjacent to Kingston's largest water feature, Hundred Acre Ponds. The Chipuxet River, the outlet for Hundred Acre Pond, passes within 300 feet of the southern end of the agricultural fields. Water is currently withdrawn during summer dry periods from the pond and stream for irrigation of the turf fields (HMM, 1991)

The gravel bank portion of the proposed site also has five small perennial ponds which are most likely the byproduct of the former gravel operation. These ponds vary in size from $1 / 5$ to 1 acre in size and have no inlets or outlets. This makes them more appropriate for water features than irrigation sources. Because of their proximity to one another, there is a potential to modify and expand these ponds into a larger manmade pond which would have the capacity to meet a portion of the proposed course's needs. An EPA sponsored testing programming is currently underway to determine the water quality of these ponds.

The upland forested portion of the proposed site also has one small perennial pond located in the northwest corner of the forested wetlands. This pond is approximately $1 / 5$ of an acre in size and is supplied by a small unnamed, intermittent stream which bisects the site. It is important to note that portions of the stream are greater 
than ten feet in width, particularly as the stream approaches the pond. This means that the RIDEM will require a 200 ' setback during the wetlands permitting process.

Groundwater is another potential source of irrigation water for the proposed project which is located within the Chipuxet River Basin and over the Chipuxet Aquifer. A study by Johnston and Dickenson (1985) characterized the aquifer as a moderate to highly permeable stratified-drift type, which is capable of delivering 100 to 1,200 gallons of water per minute (gpm). There are currently six public wells in the Chipuxet Basin: two at the Kingston Water District and four at URI (SKCCP, 1992).

Water consumption patterns for the aquifer vary dramatically due to the peak demand patterns of URI, but the average annual public yield in 1989 for the Chipuxet Aquifer was 1.3 million gallons per day (gpd) (SKCCP, 1992). Johnson and Dickerman (1985) concluded that 3.0 million gpd could be pumped from the aquifer, without significant increase in area well drawdowns, but it would cause a drying of the Chipuxet River for seven consecutive days every three years. This issue generated a tremendous amount of protest from South Kingstown residents during the review and comment stage of the proposed URI Cogeneration Project, now reportedly abandoned. This was the last major project proposed by the University. It also would have had high water consumption demands, in addition to a number of other potential environmental impacts.

If 150,000 gpd for private and industrial uses (HMM, 1991) is added to the $19891,300,00$ gpd average annual public yield, a total average annual yield of 
$1,450,000$ gpd results. If that figure is then inflated two percent a year for background population growth, an estimated adjusted average annual yield figure of $1,632,935 \mathrm{gpd}$ is obtained. That figure plus $720,000 \mathrm{gpd}$ for the proposed course (which is probably a worst case scenario given the "low input" design guidelines proposed by Devine and Casagrande) would result in a projected demand of 2,352,935 gpd which is still well below the $3.0 \mathrm{mgd}$ maximum yield figure estimated by Johnson and Dickerman (1985). This analysis suggests that irrigation needs of the proposed golf course could be met by the Chipuxet aquifer.

\subsubsection{Soils}

There have been tremendous advances in the last thirty years in the turfgrass technology and management field, and it is now possible to grow quality turf in almost any soil and climatic condition (Jones and Rando, 1974). However, economic and environmental considerations still make soil analysis a key element of the site analysis process. Unstable, rocky, or poorly drained soils can add significant costs to the construction and long term maintenance of a golf course.

The proposed site has thirteen different soil types. The following is a list of soil types, a rating of their suitability for golf course development, and a brief description of their basic characteristics. It is taken from the Soils Survey of Rhode Island (Survey) (1981). Using the criteria established in the Survey, the soils have been divided into three basic categories based on their suitability for "golf fairway" development: 
Slight Constraints - means that the soil properties are generally favorable and that the limitations are minor and easily overcome. The following soils are classified as offering slight constraints:

BhA - Bridgehamton silt loam, 0 to 3 percent slopes. This nearly level, well drained to moderately well drained soil is on outwash plains and terraces. Available water capacity is high, and runoff is slow with a depth to water table of greater than 6 feet.

EfA - Enfield silt loam, 0 to 3 percent slopes. This nearly level, well drained soil is on terraces and outwash plains. Available water capacity is moderate, and runoff is slow with a water table depth of greater than 6 feet.

Tb - Tisbury silt loam, 0 to 3 percent slopes, but are dominantly less than 2 percent. This nearly level, moderately well drained soil is in terraces, depressions and outwash plains. Available water capacity is moderate, and runoff is slow. The soil has a high seasonal water table at a depth of about 20 inches from late fall through midspring.

BmA - Bridgehampton silt loam, till substratum, 0 to 3 percent slopes. This nearly level, well drained to moderately well drained soil is on the crest of upland hills. Available water capacity is high, and runoff is slow with a depth to water table of greater than 6 feet.

ScA - Scio silt loam, 0 to 3 percent slopes. This nearly level, moderately well drained soil is in depressions of the glacial till plains. Available water capacity is high, and runoff is slow with a seasonal high water table at the depth of about 20 inches from late fall through midspring.

$\mathrm{NaA}$ - Narragansett silt loam, 0 to 3 percent slopes. This nearly level, well drained soil is on the crests of glacial till upland hills and till plains. Available water capacity is moderate, and runoff is slow with a depth to water table of greater than 6 feet.

Moderate Constraints - means that the limitations can be overcome or alleviated by planning, design, or special maintenance. The following soils are classified as offering moderate constraints:

BnB - Bridgehampton - Charlton complex, very stony, 0 to 8 percent slopes. This complex consists of nearly level to gently sloping well drained to moderately well drained soils on slopes and crests of upland wooded hills. Stones and boulders cover 2 to 10 percent of the surface of the complex. 
Available water capacity is moderate, and runoff is slow to medium with a depth to water table of greater than 6 feet.

SdB - Scio very stony silt loam, 0 to 8 percent slopes. This nearly level to gently sloping, moderately well drained soil is on glacial till plains. Stones and boulders cover 2 to 10 percent of the surface. Available water capacity is moderate, and runoff is slow to medium with a seasonal high water table depth of about 20 inches from late fall to through midspring.

ChB - Canton and Charlton very stony fine sandy loams, 3 to 8 percent slopes. These gently sloping well drained soils are on sides slopes and crests of glacial upland hills and ridges. Stones and boulders cover 2 to 10 percent of the surface. Available water capacity is moderate, and runoff is medium with a water table depth of greater than 6 feet.

Severe Constraints - means that soil properties are unfavorable and that limitations can be offset only by costly soil reclamation, special design, intensive maintenances, limited use, or by a combination of these measures. The following soils are classified as offering severe constraints:

BoC - Bridgehampton-Charlton complex, extremely stony, 3 to 15 percent slopes. These gently sloping to sloping, well drained to moderately well drained soils are on side slopes of glacial upland hills. Stones and boulders cover 10 to 35 percent of the surface of the complex. Available water capacity is moderate and the runoff is medium with a depth to water table depth of greater than 6 feet.

Rf - Ridgebury, Whitman, and Leichester extremely stony fine sandy loams. These nearly level, poorly drained and very poorly drained soils are along drainageways and in depressions in glacial till uplands. Stones and boulders cover 10 to 35 percent of the surface of the unit. Available water capacity in all three soils is moderate, and runoff is slow to medium.

Unrated Soils - means the soils properties are not currently rated by the Soil Conservation Service. The following soils are unrated:

UD - Udorthents-Urban land Complex. This complex consists of moderately well drained to excessively drained soils that have been disturbed by cutting or filling, and areas that are covered by buildings and pavement.

$\mathrm{Du}$ - Dumps. This unit consists of areas used for trash disposal. The areas are throughout the state, and most are on outwash terraces.

Figure 4.1A is a soil analysis of the agricultural fields, which is the site proposed for the front nine holes of the proposed golf course. This area is 
comprised of two soil types (BhA and EfA) which are both only slightly constrained for "fairway development". Both soil types drain well and have slow runoff characteristics, medium to high water capacity, and a low water table. The land currently functions as a turf farm which produces high quality commercial sod. Recent field investigation suggests that any ponding and drainage concerns resulting from the lands "extremely flat" profile are unwarranted.

Figure 4.1B is a soil analysis of the gravel bank, disposal area and upland forested portions of the proposed site. This area is comprised of all 13 soil types listed in the inventory. In general terms, the overall quality of the soils in this portion of the proposed site is relatively poor compared to the agricultural fields, with approximately 40 percent of the site falling into the severe or moderately constrained categories. The severely constrained soils create a barrier of very stony, wetland soils (Rf, BoC) which effectively divides the parcel in half. Moreover, roughly 20 percent of the site is either abandoned dump (Du) or gravel bank (UD) devoid of all topsoil and substratum material. This area will require additional capping and extensive remediation and restoration to become productive acreage for the project.

It is important to note that moderately constrained soils $(\mathrm{BnB}, \mathrm{ChB}, \mathrm{SdB})$ are impacted by "extremely stony" conditions (10-35 percent land covered by stones) and not wetlands or drainage related problems. These stones however, are categorized as "large stones" which are defined as "rock fragments ten inches or more across". This suggests that these areas can be reclaimed using heavy construction equipment, but there will be a significant cost associated with it. 


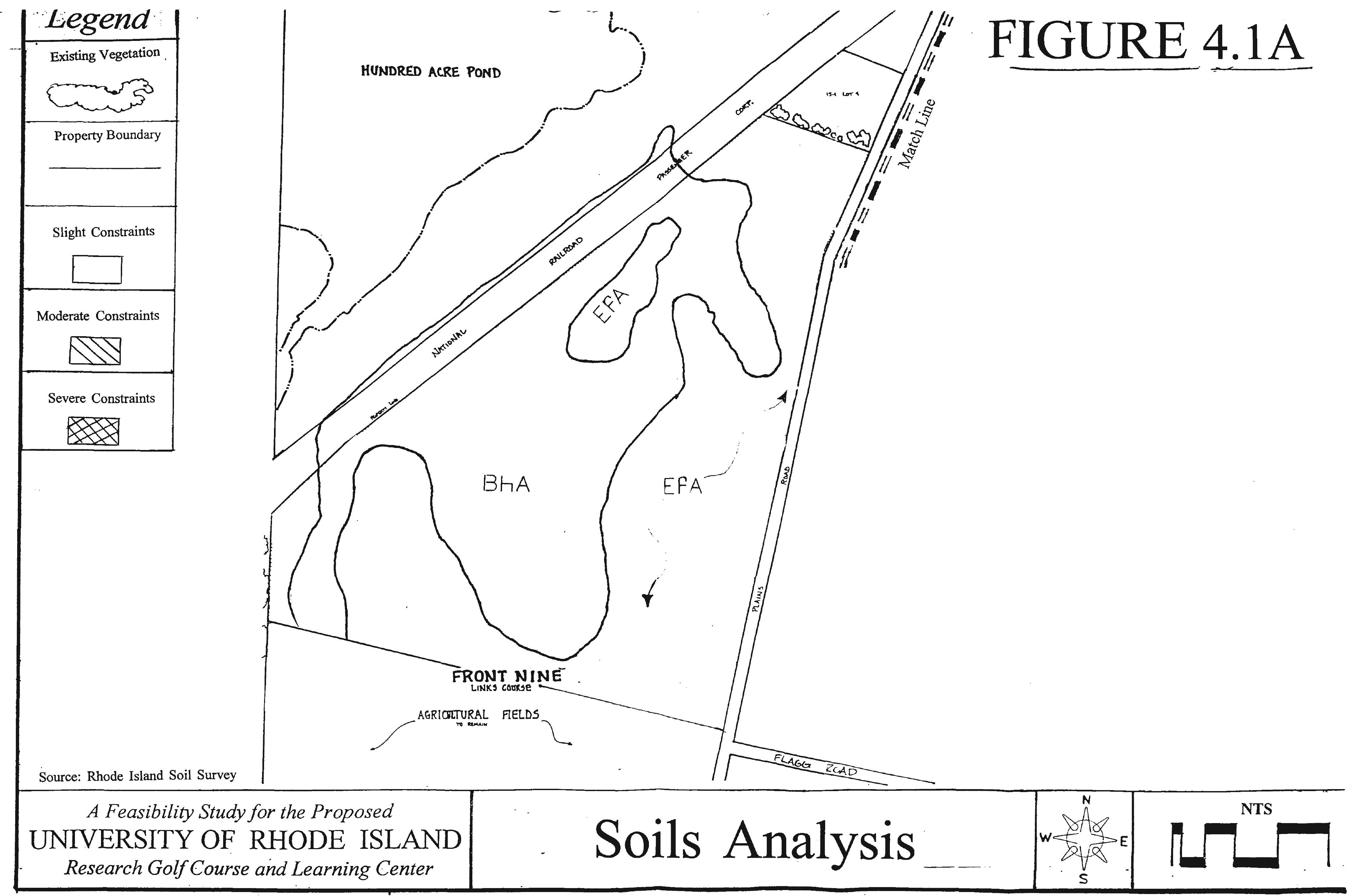




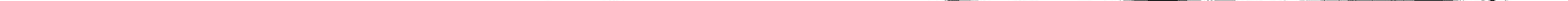


Finally, approximately 40 percent of the parcel is comprised of slightly constrained soils (Tb, EfA, ScA, BmA, NaA). The EfA, NaA and BmA soil characteristics are similar, and in general terms are excellent for golf fairway development. The $\mathrm{Tb}$ and $\mathrm{ScA}$ have a high available water capacity and runoff is slow, but they suffer from a high seasonal depth to water table of only about 20 inches from late fall through midspring. High water table is not typically considered a constraint to golf course development, but may pose a problem during the construction phase of the project.

\subsubsection{Vegetation}

A vegetation analysis was conducted using the U.S. Geological Survey, Kingston/Slocum Quadrangle Maps, the United States Department of the Interior, Kingston/Slocum - Kuppa and McConnell (1972), Forest and Wetland Vegetation Maps, and site research. The proposed site encompasses an extremely diversified mix of existing land uses, each with a distinct vegetative cover including agricultural fields, upland forrest, a quarry and a disposal area. The largest of these land uses is the agricultural use which is currently operating as a turf farm. As one might expect, the general diversity of plant life is rather low, with shrub and hardwood trees limited to the field perimeter areas. It is anticipated that the limited vegetative cover will dramatically reduce the costs to clear, grub and shape the site, but these savings will be partially offset by increased grading and landscaping costs.

The quarry and landfill area offers a more rugged and diversified vegetative cover with a mix of shrub growth, small trees, ponds and brush covered excavation 
areas. The ponds, coupled with many 20 foot mounds and rock outcroppings already present an attractive demonstration of plant succession (Devine and Casagrande, 1994). This area will require extensive remediation and ecological restoration.

The forested portion of the proposed site offers the most highly diversified vegetative cover. This area is home to abandoned, overgrown agricultural fields, dense and sparsely forested hardwood areas, and dense shrub and understory growth. This area will require extensive clearing and grubbing, or possibly could serve as a source of vegetation which could be transplanted to the agricultural fields, gravel pit and disposal area.

A review of South Kingstown Plat Maps for this upland area also indicates the presence of a small, deciduous wooded swamp approximately 10-12 acres in size (Golet and Larson, 1974). This swamp is sparsely treed and home to a stream which feeds a small freshwater pond in the northwest corner of the wetlands. The actual size of the wetlands complex is not known and varies depending on what docuement is referenced. A map from a Route 138 corridor study by Gordon Archibald Associates for RIDOT, which used field research and delineation techniques, suggests that the wetland is significantly larger than the South Kingstown plat maps indicate. Use of the wetland acreage may be possible, but it would require a permit from RIDEM and the Corps. This is a significant issue which may affect the amount of usable acreage in the proposed site. 


\subsubsection{Constraints Map and PCP Comparison}

A constraints map was developed in an overlay format at $1^{\prime \prime}=100^{\prime}$ scale in order to identify any elements of the proposed design which need to be redesigned to help mitigate adverse environmental impacts, and reduce design, permitting and construction problems. In general terms, the results of the comparison were quite positive and suggest that the site is well suited for golf course development. There were however areas of concern.

First, the best available information suggests that the wooded swamp in the upland, forested portion of the proposed site is significantly larger than indicated on the PCP. Moreover, portions of the intermittent stream are greater than ten feet in width and thus will require a $200^{\prime}$ foot setback. The PCP also does not show or account for the small perennial pond in the northwest portion of the wooded swamp. It is highly likely that 15 th fairway/green and the 11 th hole tee are within the wetland area. The impact of this finding on the design is not terminal however, because there is excess acreage east of hole \#14 which would allow the course to shift east, away from the wetlands area.

Second, soils $\mathrm{BnB}, \mathrm{Chb}$, and $\mathrm{SdB}$ which comprise roughly 25 percent of the upland, forested portion of the proposed site are categorized as moderately constrained because of their "extremely stoney" characteristics. This will impact the cost to construct holes \#10,\#11, \#13, \#15 and \#18.

Third, soils ScA and SdB which comprise roughly 40 percent of the upland, forested portion of the proposed site are constrained by a high water table at a depth 
of approximately one to three feet. As the design of the course progresses, careful consideration should be given to the proposed grading plan for these soils and the scheduling of construction activities.

Finally, while no topographic map of the agricultural field was found, it is reasonable to assume that this area will fall into the "extremely flat" category discussed earlier. The drainage and ponding problems typically associated with "extremely flat" areas are not anticipated because of the quality of the soils. However, the agricultural fields will require substantial amounts of fill to shape fairways and create raised features such as tees and greens. These costs are at least partially mitigated by the reduced clearing and grubing costs.

\subsection{Manmade Site Constraints}

An inventory was performed on the proposed site to determine the status of the following manmade constraints: Utilities and Services, Circulation and Access, and the abandoned URI Disposal Area.

\subsubsection{Utilities and Services}

Field research and interviews with South Kingstown's Utilities Department and the URI Facilities/Engineering officials indicates the following status:

a. Gas - It is available throughout most portions of the Kingston Campus but not on Plains Road north of Flagg Road.

b. Water - The northern portion of Plains Road is currently served by the URI water system. Based on discussions with URI facilities personnel the URI water system may not handle the golf courses total irrigation needs and thus dedicated wells would also be required within the site (Wilcox, 1995) 
c. Sewer - No sewer is available on Plains Road. Access to the URI sewer system is available on Flagg Road, approximately 200' east of the intersection of Plains and Flagg Roads.

d. Electricity - The proposed site has an electric service which extends past the location of the proposed club house to an existing URI radio tower located in the forested portion of the site.

\subsubsection{Circulation and Access}

According to the NGF (1989) the ideal golf course site should be easy to find, accessible, visible, and convenient to a major highway so it can attract golfers from a wider area. The proposed site, which is located less than $1 / 2$ mile from Route 138, ten miles west of Route 95, and two miles west of Route 1 , seems to meet most of these requirements. Figure 4.2 shows the primary campus entry points and the routes to the proposed site. Primary routes to the site include Plains, Flagg and Upper College Roads. It is anticipated that site access will be achieved through the existing unpaved entry point. It is important to note that the proposed site is fairly isolated and will not get the benefit of "drive-by" exposure from the heavily traveled Route 138. This disadvantage can be overcome with signage and an aggressive marketing strategy, but an allowance for these expenses must be made in the project budget.

The campus is also accessible through other modes of transportation including the Amtrak railroad station which is two miles away in Kingston, public and private buses from New York and Providence which stop daily at the Memorial Union, and air service which is available 35 minutes away in Warwick at T.F. Green Airport. 


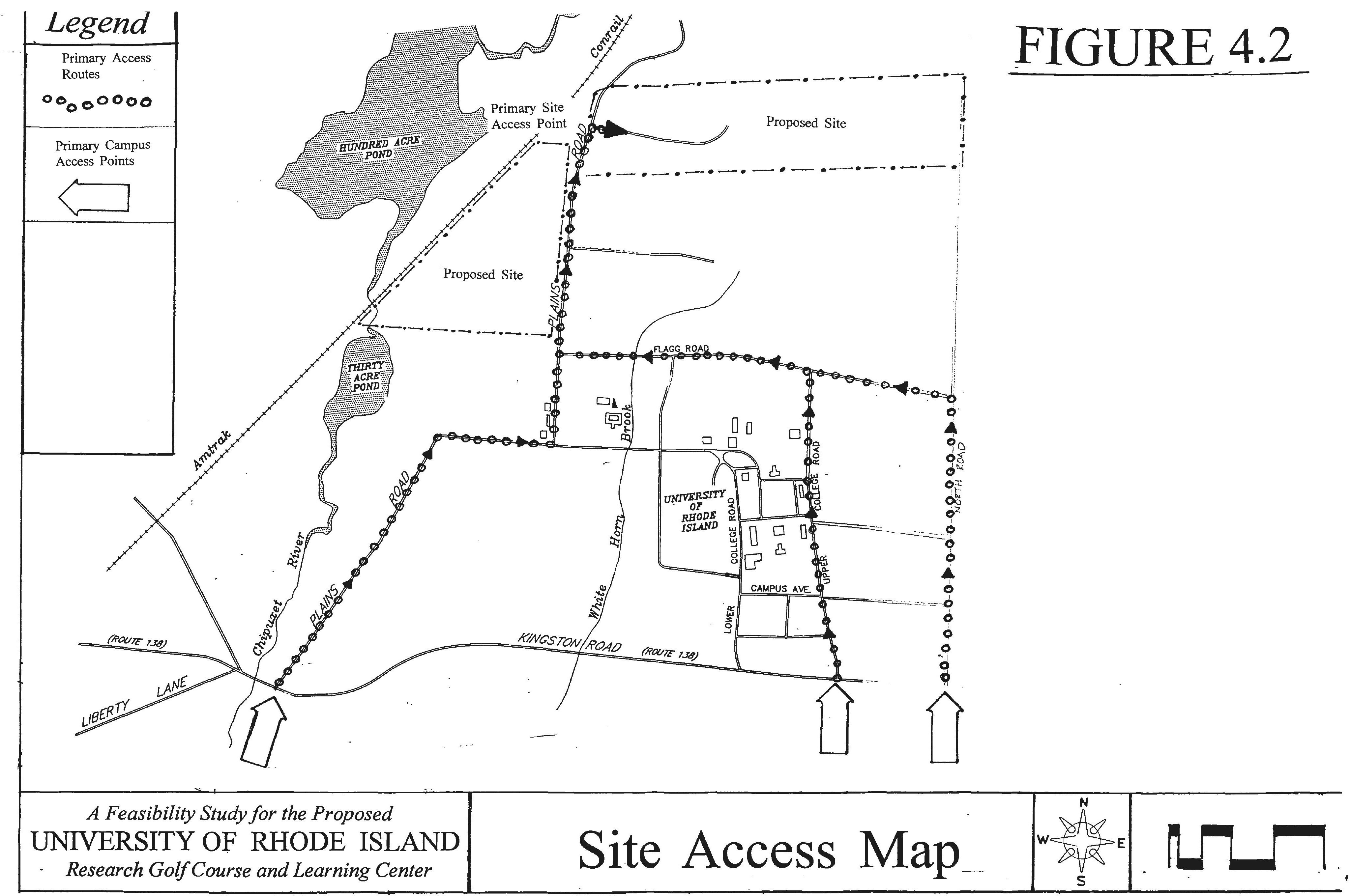


The following access and circulation problems were identified based on the Prelimary Concept Plan (PCP), Dated October, 1994 (Reference Figures 1.1A \& 1.1B):

a. The location of the access road, parking lot, clubhouse and maintenance barn dictates that all customer, staff, deliveries and grounds keeping traffic goes through one access point. It is customary to split delivery and grounds keeping traffic from customer traffic flows.

b. The main access point is also directly adjacent to surrounding residential land uses which maximizes the impact of the traffic flows on the neighborhood. A possible solution would be to flip the location of the parking lot and clubhouse with the target course. Another possible solution would be to shift all the ancillary facilities south of the links course and have the course start at hole four. This would help mitigate impacts on the residential neighborhood.

c. The location of the main access point requires that golfers travel Plains Road to move between the front and back nine. A secondary access point for golf cart and foot traffic should be added south of the target course for safer access to the front nine (assuming the above referenced alternative is not feasible).

d. The location of the putting course and parking lot should be flipped to make access to the clubhouse more convenient, particularly to facilitate golf bag drop-off. Moreover, the location of the parking lot is currently a high quality turf field which makes it more ideally suited for conversion to the putting course.

e. According to Muirhead and Rando (1994) hole number one should be located adjacent to the club house for greater management control and convenience.

f. The length of time it takes to play a round on the par3/par4 layout is likely to be significantly longer than most executive courses because the player is still required to walk/ride the full distance of the course. This will affect revenues because the course will not generate as many rounds per day. Moreover, the course may not appeal to older players because of the additional yardage.

g. The additional tee's required for the par3/par4 layout may confuse players and slow play on the full length course. At a minimum the 
course will require additional signage and a clear pamphlet to avoid confusion.

h. The distance between the eighth green and ninth tee seems excessive. The same holds true for the distance between the twelfth green and thirteenth tee.

i. No official rules define course length, but the NGF (Muirhead and Rando, 1994) recommends a minimum course length of 6,000 and 7,200 yards for regulation and championship play respectively. The current design does not meet these standards and this may affect the marketability of the golf course.

\subsubsection{Summary of the EPA Final Listings Report (FLR)}

The abandoned URI Disposal Area comprises approximately 12 acres of the abandoned 17 acre sand and gravel excavation area, sometimes referred to as the URI Gravel Bank. (The URI Disposal Area and the West Kingston Dump are currently being treated as one site for the purpose of the preliminary investigation studies). The Disposal Area and Gravel Bank were brought by the University in 1936 as part of a larger 127-acre parcel. Gravel excavation and dumping started in the late 1940's and was continued on and off for a period of 42 years until the dump was closed in 1987 under RIDEM order (EPA, 1990).

The FLR report was prepared for the EPA (1990) in order to document how groundwater has been impacted by hazardous substances which are attributable to the URI Disposal Area (and the West Kingston Town Dump located just south of this area). The report identified three separate fill areas which operated at various time and durations over the course of the URI Disposal Area's history: FA1, FA4, FA5 (See Figure 4.3). FA1 is the oldest fill area which was active from 1945-61. Activity at FA4 started sometime during the period 1962-72 and ended by 1975 . 


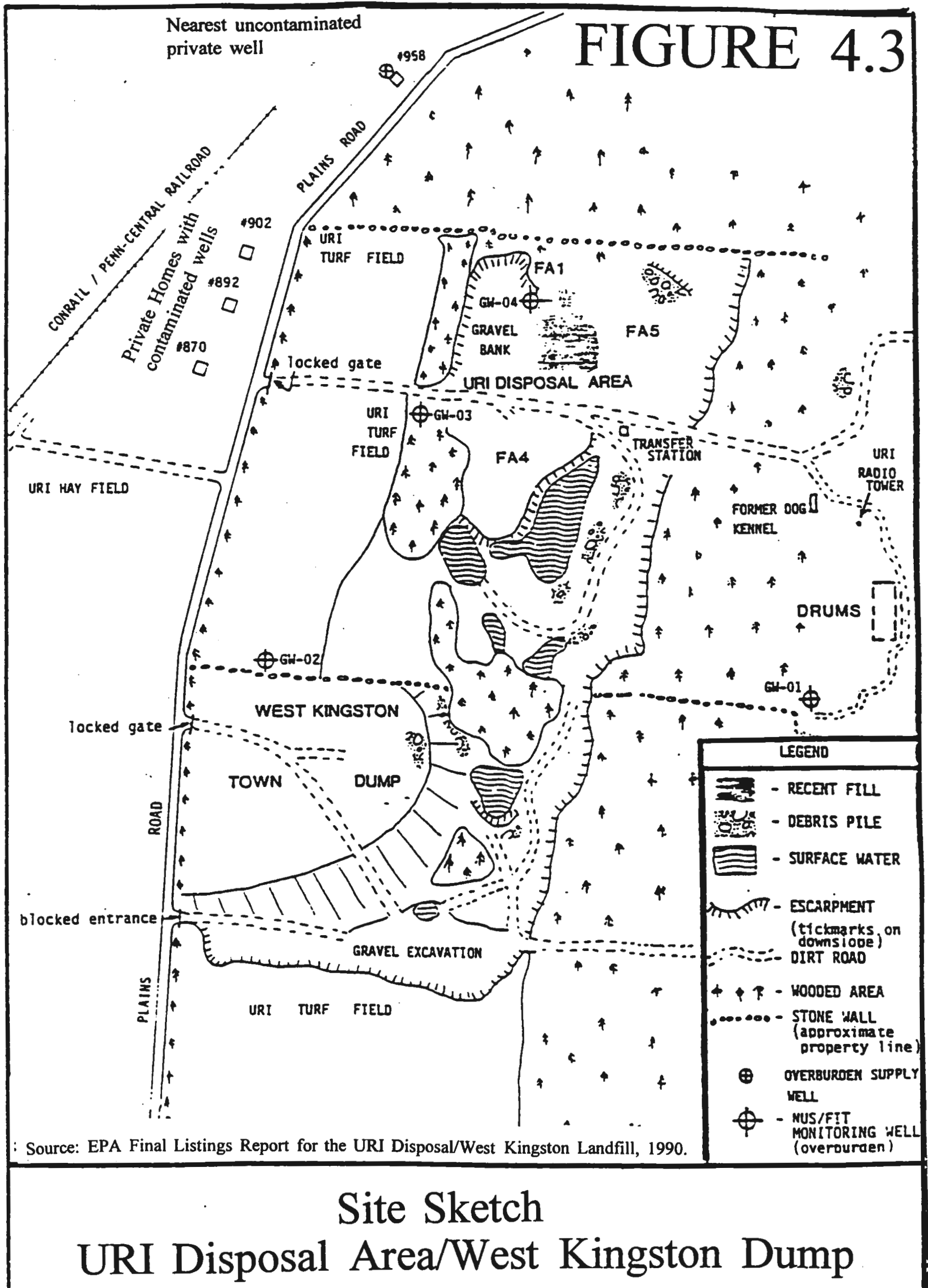


Activity then shifted to FA5 which was active until 1980 . It is important to note that Muirhead and Rando (1994) recommend that a landfill be allowed to age a minimum of 20 years before construction of golf courses to prevent damage associated with subsidence. This suggests that FA5 will not be properly aged (or fully settled) until the year 2000.

The estimated volume of fill material for FA4 and FA5 is 6,096 and 11,514 cubic meters, respectively. No fill figures were available for FA1. The areas are primarily filled with solid wastes such as construction debris, stumps, old furniture, tires and lab equipment. The EPA (1990) report documents the disposal of small quantities of toxic materials such as empty paint cans, oil cans and pesticide containers. On a more serious note, the report also documents the presence of 12 50-gallon drums of "unknown origin and content" scattered throughout a small portion of the site.

Over the course of many years all three fill areas have been capped with clean fill and graded. The procedures used during the capping process are unknown, but the presence of surface debris in many locations suggests that it was not done in conformance with EPA standards (EPA, 1990).

A battery of geohydrological surveys and ground/surface water monitoring programs has been conducted on the site by the Town of South Kingstown, EPA, RIDEM, RIDOH, URI, and their respective consultants over the years. These tests have conclusively documented the following conditions:

a. The groundwater has been locally contaminated by a plume of leachate-contaminated groundwater that originated from both disposal 
sites and has migrated west and downgradient at least 1,200' towards Hundred Acre Pond (EPA, 1990)

b. Groundwater samples collected from test wells in September 1989 indicated traces of five volatile organic compounds (VOC's) and 13 inorganic elements. The level of contamination varied from 3 to 124 times the samples taken from a background test well which was east, and upgradient of the two sites (EPA, 1990).

c. Analysis of the surface water samples collected by RIDEM from the pond adjacent to FA4, located on the URI property, showed the presence of the same VOC's detected in the private wells (EPA, 1990).

d. Testing by the RIDOH in 1988 concluded that the plume had contaminated three private bedrock wells located approximately 875' northwest and downgradient of the two disposal areas. The levels and types of contaminants found in the private wells was consistent with the samples taken in the test wells at the dump site (EPA, 1990).

e. Ground water supply wells which are potentially threatened by contamination include: a private well located $1,000^{\prime}$ northwest of the URI property; the URI supply wells located 0.7 mile southwest and downgradient of the disposal area; and the West Kingston Water District wells located 1.35 miles southwest and downgradient of the disposal area (EPA, 1990).

f. Documentation of the hazardous waste disposed at the URI Disposal Area, prior to 1978 does not exist.

\subsection{Implications of the EPA Final Listings Report (FLR)}

The implications and potential impacts of the FLR on the proposed project's schedule, design, and cost are far reaching. According to James Brown (1995), the EPA - Region I Project Manager, of the URI Disposal Area/West Kingston Dump, as a result of the findings of the FLR, the disposal sites were added to the EPA National Priorities List (NPL) and now fall under EPA jurisdiction. Getting a site 
assigned to the NPL, is only the second step in the seven step Superfund remediatiom process depicted in Figure 4.4.

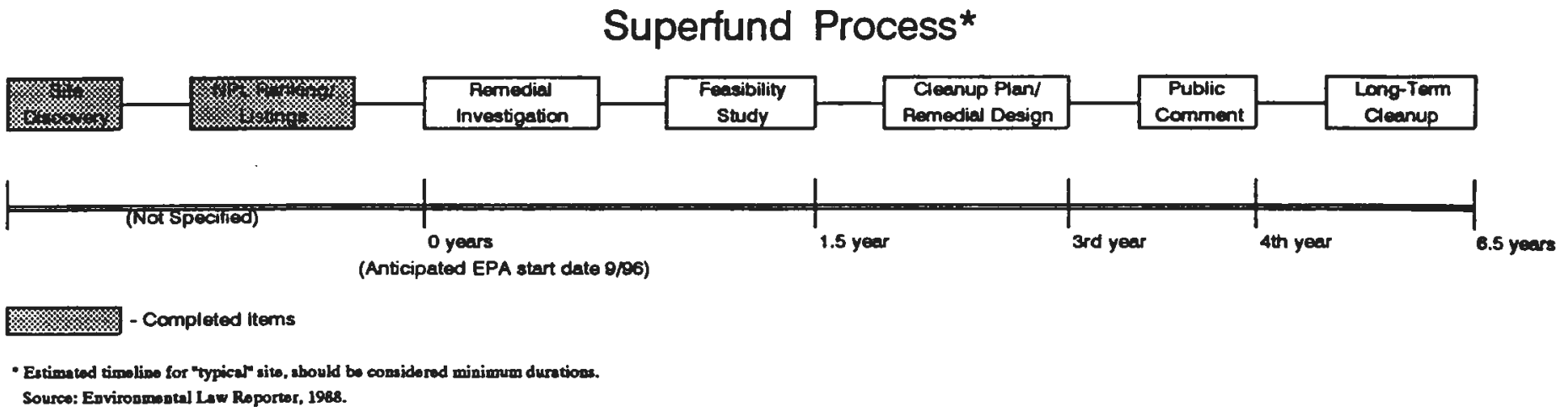

This figure was developed using EPA literature, which estimates a six-and-ahalf year duration for a typical Superfund cleanup. Brown (1995) cautioned that these EPA durations are conservative and should be considered minimums. Actually cleanup would probably would run longer. Brown (1995) indicated that the EPA funding for the Remedial Investigation and Feasibility Study (RI/FS) was not slated until the third-quarter of the FY 1996 budget.

While no definitive timeline has been established for the proposed golf course project, incorporating the URI Disposal Site into the project will have obvious ramifications on the project schedule. It is reasonable to assume that the construction of the golf course will have to preceed the remediation of the proposed site. Brown (1995) noted that a proactive approach on the part of potential responsible 
parties (PRPs) such as the URI and South Kingstown would help dictate the pace of the remediation process.

The Superfund Amendment and Reauthorization Act of 1986 (SARA) creates strong new incentives for PRPs to participate and shape the RI/FS process and the selection and design of the remedy (Environmental Law Institute, 1988). The remediation element of the proposed golf course is an excellent opportunity for URI to participate in the Superfund process and help tailor a cost-effective solution, which limits the University's liability. According to Brown (1995), knowledge of the postcleanup land use gives the EPA more latitude when establishing cleanup standards for the project.

The specific impacts of FLR findings on the design of the course are hard to predict until the scope of the contamination and remediation has been defined by the RI/FS. At a minimum the following design impacts can be anticipated:

a. The 10th tee and fairway, which fall within FA5, will have to be relocated outside the disposal area to avoid construction delays.

b. Critical ancillary facilities areas such as the clubhouse should be relocated further away from the landfill areas to reduce the chances for a delay associated with the remediation activities.

c. The design should incorporate substantial setbacks and natural buffers around all fill areas to mitigate the impacts of remediation activities on course play.

d. In addition most golf courses sited over disposal areas incorporate design features to mitigate landfill gases, uneven settling or subsidence, and leachate outflows (Muirhead and Rando,1994).

The specific cost impacts of the FLR findings on the proposed project are also hard to predict with any certainty. It is important to note that SARA does not allow 
the EPA to enter into a Superfund financed cleanup of a state-operated site unless the state agrees to cover 50 percent of the costs, and all of the post-cleanup operational and maintenance costs (Environmental Law Reporter, 1988). Brown (1995) estimated the cost of the RI/FS alone (for the two sites) to be in the range of $\$ .75$ to $\$ 1.0$ million. This figure does not include the administrative, legal, design, and remediation costs. The average cleanup per site under CERCLA (1980-86) escalated from $\$ 2.5$ to $\$ 8.3$ million, approximately 30 percent of these figures is attributed to administrative costs (Environmental Law Reporter, 1988). Costs, however, vary dramatically depending on the site, the nature of the contamination, and the ability of the EPA to identify PRPs and distribute financial liability accordingly.

\subsection{Summary of Findings}

The site analysis conducted in this chapter identified the following natural and manmade physical constraints to golf course development on the proposed site:

a. With the exception of excavation sites in the gravelbank area, the slope analysis found that no portion of the site to be constrained by steep slopes.

b. Field research of the agricultural fields suggests that they fall in the "extremely flat" category and will require substantial amounts of fill to shape fairways and create raised features such as tees and greens. This will impact the cost to construct the course.

c. There is probably sufficient groundwater capacity within the Chipuxet aquifer to meet the project's irrigation needs. Moreover, there are other small ponds within or adjacent to the site which could serve as potential water sources. 
d. Portions of the soils in the gravel bank, disposal area, and upland forested areas suffer from a variety of constraints including high stone content, high water tables, unstable soils and a lack of topsoil and substratum material.

e. The best available information suggests that the wooded swamp in the upland, forested portion of the proposed site is significantly larger then indicated on the PCP.

f. Studies indicate that the groundwater has been locally contaminated by a leachate plume which originates from the disposal sites and has migrated west at least 1,200' towards Hundred Acre Pond.

g. The URI Disposal Area is in the early stages of a long EPA Superfund cleanup process which will have significant adverse impacts on the design, schedule, and cost of the proposed project.

h. The remediation element of the proposed golf course is an excellent opportunity for URI to participate in the Superfund process, and help tailor a cost-effective design solution which limits the University's liability. 


\subsection{References}

Jones, Ress and Guy Rando. 1974. Golf Course Development. The Urban land Institute, Washington, D.C.

Muirhead, Desmond and Guy Rando. 1994. Guidelines for Planning and developing a Public Golf Course. Jupiter, Florida. National Golf Foundation.

Moran, James. 1991. Golf Course Feasibility Study for Block Island. University of Rhode Island.

HMM Associates, Inc. 1991. Environmental Information Document for the URI Cogeneration Project. Boston, MA.

Louis Berger and Associates, Inc. 1992. Town of South Kingstown Comprehensive Community Plan (SKCCP). Providence, RI.

United States Department of Agriculture Soil Conservation Service. 1981. Soils Survey of Rhode Island.

Devine, Barry and R.A. Casagrande. The University of Rhode Island College of Resource Development Golf Course Educational and Research Facility: $A$ Project Overview. August, 3, 1994.

Golet, Francis and Joseph Larson. 1974. Classification of Freshwater Wetlands in the Glaciated Northeast. Bureau of Sport Fisheries and Wildlife. Resource Publication 116. Washington, D.C.

Personal Interview. Raymond Wilcox. University of Rhode Island, Engineering and Facilities Department. June 1, 1995.

National Golf Foundation. 1989. Guidelines for Planning and Developing a Public Golf Course. Jupiter, Florida. National Golf Foundation.

NUS Corporation. 1990. EPA-Final Listings Inspection Report for the West Kingston Town Dump/URI Disposal Area. Boston, Massachusetts.

RIDOH (Rhode Island Department of Health). 1988. Data base printout, Private Well Survey program History Report, 480 URI/Plains Road Dump Site. December 13.

Personal Interview. James Brown. EPA-Region I Program Manager.

June 15, 1995.

Environmental Law Institute. 1988. Superfund Deskbook: The Environmental Law Reporter. Washington, D.C. 
CHAPTER FIVE - MARKET ANALYSIS 


\subsection{Introduction}

The purpose of this chapter is to evaluate the supply and demand for golf in the market area surrounding the proposed golf course. The first task in this chapter will be to define and delineate the primary and secondary market area. This will be followed by an overview of key demographic indicators which help determine the economic demand for golf in the market area. Next, a demand analysis will be performed using NGF participation models and statistics. Supply side figures will then be developed by conducting a market survey of all existing and proposed golf courses. Finally, an estimated market potential and market share (or capture rate) will be developed.

\subsection{Market Definition and Delineation}

The NGF (1989) defines the primary market "as the area which most golfers would be happy to travel if they could play every day." More specifically, NGF (1991) research indicates that "on average nationally, golfers will travel about ten miles (or 17 minutes) one way to play their most frequently played golf course."

The NGF (1989) defines the secondary market "as the area from which golfers would be willing to travel if necessary to play golf regularly". More specifically, NGF (1991) research shows that average golfers will travel just over 20 miles (or 32 minutes) to golf regularly on a good course. NGF (1991) research also shows that 52 percent of all golfers are willing to travel in excess of 20 miles to regularly play a good course. 
These figures however must be balanced against any manmade or natural features of the market area which constrain travel time and distance. This includes features such as population density, road quality, road capacity, speed limits, bridges, toll booths, rivers, lakes, railroads, etc. (NGF, 1989).

The primary market area for the market analysis was established at the NGF recommended 10 mile radius. However, because of the above referenced constraint the secondary market areas for the project was held to 20 miles. In particularly, a review of Route 138, the primary east-west link for most South County and URI trips, indicated heavy traffic conditions at both peak and non-peak period. Slow travel is common particularly on the portion of Route 138 from the URI Campus to Route 95 which is only 10 miles in distance, but takes approximately 20-25 minutes to drive during peak hour conditions.

The market area is comprised of 25 Rhode Island towns and encompass all of Washington, Kent, and Newport Counties. The market area also encompasses a portion of Bristol and Providence Counties and southeastern Connecticut.

\subsection{Market Overview}

This section of the analysis is designed to provide the reader with background information on the economic vitality of the market area. Key demographic and economic indicators such as population trends, median age, median household income, employment trends, and employment by industry statistics help provide valuable insight into the strength of the golf market. 


\subsubsection{Population Trends}

Washington County, which dominates the primary market area, witnessed rapid population growth for the period 1980 to 1990 with an annual average growth rate of 1.8 percent, and an overall increase of 16,689 persons. The growth rate in Kent and Newport Counties was more moderate with an annual average increase of .06 percent, which was more in line with the State's average. The overall population increase for the three major counties within the market area for the period 1980 to 1990 was 29,472 persons (See Table 5.1).

Population projections made by RI Division of Planning (1989) suggest that the growth rate for the period 1990 to 2000 will be more gradual for both the state and the three major counties within the market area. It is anticipated however that Washington County will continue to outpace the rest of the state with annual average growth rate of .07 percent.

It is important to note the estimated state annual average growth rate of 0.3 percent is well below the national average of 0.8 percent. Because of this, the proposed golf course will have to rely on greater penetration of the existing market capacity in order to be successful (NGF, 1993).

TABLE 5.1 - Population Trends

\begin{tabular}{lcrlrl}
\hline \multicolumn{1}{c}{ PLACE } & \multicolumn{1}{c}{1980} & \multicolumn{1}{c}{1990} & \multicolumn{1}{l}{$\%$} & \multicolumn{1}{l}{2000} & $\%$ \\
\hline Washington Cty. & 93,317 & 110,006 & $18 \%$ & 117,689 & $7 \%$ \\
Kent County & 154,163 & 161,135 & $5 \%$ & 169,716 & $5 \%$ \\
Newport Cty. & 81,383 & 87,194 & $7 \%$ & 92,442 & $6 \%$ \\
Rhode Island & 947,154 & $1,003,464$ & $6 \%$ & $1,037,352$ & $3 \%$ \\
\hline
\end{tabular}

Sources: U.S. Census $1980 \& 1990$.

R.I. Division of Planning, Housing Data Base, 1990. 


\subsubsection{Median Age}

The median age within the market area for the period 1980 to 1990 was below the national average. Median age figures for the United State, Rhode Island and the major counties within the market area are presented in Table 5.2.

TABLE 5.2 - Median Age Trends

\begin{tabular}{lccc}
\hline \multicolumn{1}{c}{ PLACE } & 1980 & 1990 & 1996 \\
\hline Washington County & 29.7 & 32.7 & $34.5^{*}$ \\
Kent County & 31 & 35.7 & $37.5^{*}$ \\
Newport County & 30.2 & 33.7 & 35.6 \\
Rhode Island & 31.7 & 33.9 & 36.0 \\
United States & 33.2 & 35.6 & 38.8 \\
\hline \multicolumn{4}{c}{ Sources: U.S. Census, 1980 \& 1990. } \\
\multicolumn{4}{c}{ NGF, Market Analysis Newport Country Club, 1993. } \\
\end{tabular}

Generally speaking, a comparatively young population in a market area tends to reduce overall frequency (of golf play) to less than what the frequency may otherwise be for a state or region as a whole (NGF, 1993). More specifically, younger persons exhibit higher golf participation rates, but older players play more frequently. This finding is particularly pertinent in the case of Washington County were the median age is 2.9 and 1.2 years below the national and state medians age figures, respectively.

It is important to note, however, that population studies by the RI Division of Planning (1989) show rapid increases in the 75 years or older age cohort, and further predicts significant increases in the middle age cohorts of 45 to 64 years. 
These groups will comprise approximately 45 percent of the total state population by the year 2010. This fact has strong implications for the future golf market because these age brackets display significantly higher "frequency of play" characteristics.

\subsubsection{Median Household Income Trends}

One of the primary economic indicators for any market study is the personal income level of residents within the market area. Figure 5.3 shows the basic household income trends for the United States, Rhode Island, and the three major counties within the market area.

TABLE 5.3 - Median Household Income Trends

\begin{tabular}{llllll}
\hline \multicolumn{1}{c}{ AREA } & 1980 & 1990 & $\%$ & 1996 & $\%$ \\
\hline Washington Cty. & $\$ 19,960$ & $\$ 38,488$ & $93 \%$ & $\$ 47,759^{*}$ & $24 \%$ \\
Kent County & $\$ 22,263$ & $\$ 42,929$ & $93 \%$ & $\$ 53,269^{*}$ & $24 \%$ \\
Newport County & $\$ 18,024$ & $\$ 39,910$ & $121 \%$ & $\$ 54,538$ & $37 \%$ \\
Rhode Island & $\$ 19,448$ & $\$ 37,500$ & $92 \%$ & $\$ 51,675$ & $38 \%$ \\
United States & $\$ 16,886$ & $\$ 29,421$ & $74 \%$ & $\$ 36,546$ & $24 \%$ \\
\hline
\end{tabular}

NGF, Market Analysis Newport Country Club, 1993.

* Author's Projections

During the period 1980 to 1996 , median household incomes in the three major counties which comprise the market area exceed both the state and national figures and fall into a range which the NGF (1994) research correlates with higher golf participation rates. According to the NGF (1993) however, the implications of higher than average income levels in the market area are at least partially mitigated by a higher cost of living within the state as a whole. 


\subsubsection{Employment Trends}

Figure 5.1 summarizes unemployment trends for Rhode Island and the United States for the period 1980 to 1995 . The state unemployment rate peaked in 1982 at 10.3 percent and then steadily decreased to 3 percent in 1988 . From the period 1982 to 1988 both Rhode Island and New England enjoyed strong economic growth and unemployment figures were often significantly below the national averages. Beginning in 1989, the unemployment rate began to rise sharply and peaked in 1991 at 8.8 percent, which was 2.1 percent higher then the national average. Unemployment figures have dropped since 1991 and currently fluctuate around 6.5 percent, which is significantly higher then the national average of 5.75 percent.

Figure 5.1

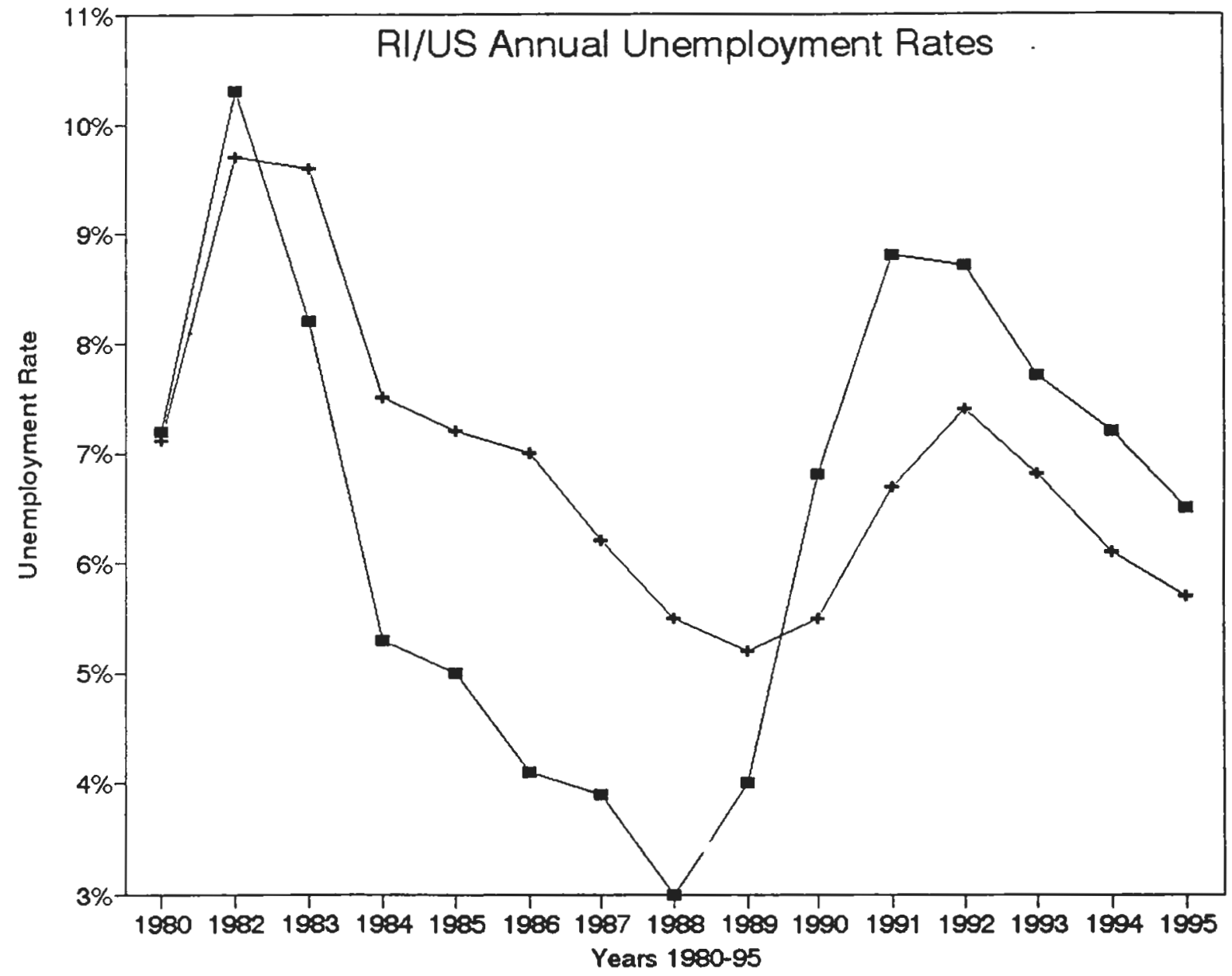

- - Rhode Island + United States 
'Table 5.4 shows Rhode Island's salaried workers by industry type for the period $1986-1994$. The most significant finding from this table is the eight percent decrease in manufacturing's share of the total employment. These jobs have been partially replaced by new jobs in the service industry which increased its share of the total employment by seven percent over the same period. The other five major industries have remained fairly constant and the overall level of job growth has remained flat.

TABLE 5.4 - Nonagricultural \& Salaried Workers by Industry (Per 1,000 workers)

\begin{tabular}{|c|c|c|c|c|c|c|}
\hline Industry Type & 1986 & $\begin{array}{l}\% \\
\text { Total }\end{array}$ & 1990 & $\begin{array}{l}\text { \% To- } \\
\text { tal }\end{array}$ & 1994 & $\begin{array}{l}\% \\
\text { Total }\end{array}$ \\
\hline Manufacturing & 119.8 & $28 \%$ & 99.5 & $22 \%$ & 86.0 & $20 \%$ \\
\hline Construction & 17.4 & $4 \%$ & 18.2 & $4 \%$ & 11.8 & $3 \%$ \\
\hline $\begin{array}{l}\text { Trans., Comm. \& } \\
\text { Utilities }\end{array}$ & 14.6 & $3 \%$ & 15.8 & $4 \%$ & 14.4 & $3 \%$ \\
\hline $\begin{array}{l}\text { Wholesale \& Retail } \\
\text { Trade }\end{array}$ & 99.3 & $23 \%$ & 97.9 & $22 \%$ & 95.5 & $22 \%$ \\
\hline $\begin{array}{l}\text { Finance Insur. \& } \\
\text { Real estate }\end{array}$ & 25.0 & $6 \%$ & 27.1 & $6 \%$ & 25.1 & $6 \%$ \\
\hline Services & 109.4 & $25 \%$ & 128.4 & $29 \%$ & 139.9 & $32 \%$ \\
\hline Government & 58.0 & $13 \%$ & 63.2 & $14 \%$ & 61.8 & $14 \%$ \\
\hline TOTAL & 433.5 & $100 \%$ & 450.1 & $100 \%$ & 434.4 & $100 \%$ \\
\hline
\end{tabular}
Sources: $\quad$ NGF, Market Analysis Newport Country Club, 1993.

Rhode Island Department of Economic Development, Economic Trends Report, Dec. 1994.

Many of the gains made in the service sector are a result of tourism industry which has become one of the state's largest and fastest growing industries. Tourism currently supports an estimated 25,000 to 30,000 jobs and generates over one billion dollars in revenue for the state (NGF, 1993). Even with the economic slowdown of the early 1990's tourism revenues have increased an average of six percent a year 
since 1988, and brought an estimated 29.5 million travelers to the state in 1992 (NGF, 1993). While approximately 58 percent of these visitors are "pass-through travelers", it is anticipated that rounds of golf played by tourists will be an important component of the market demand for the proposed course.

\subsection{Market Demand Analysis}

For the sake of clarity the potential customers within the market area have been divided into three categories. The largest category includes permanent residents who live within the market area. The second category includes the tourists who visit or vacation within the market area. The last category includes URI students, staff, faculty and alumni who come to the University for classes, work or pleasure. The demand figures will be calculated for each group and are designed to provide a "present day" (1995) estimate of the golf market. As of this writing no start or completion date has been established for the project. Because of this no "future build" scenario will be analyzed.

It is important to note that the underlying goal of this section is to provide a conservative understanding of the current local golf market. This analysis deliberately excludes factors such as:

a. An average annual increase of seven percent (for the last three years) in the number of new golfers entering the game (NGF, 1989).

b. The innovative $\mathrm{Par}$ 3-4-5 design concept which project proponents feel will make the course more attractive to a wider spectrum of golfers (Devine, 1995). 
c. The fact that a new course will provide local golfers with an increased opportunity for play (Devine, 1995).

The techniques and statistics for estimating the potential demand within the market area were borrowed from a market analysis prepared by the NGF (1993) for the Newport Golf Club. All the statistics were developed by the NGF (1993) for Rhode Island or the New England Region, and thus are assumed to be accurate for the proposed market area. Numerous assumptions were made to arrive at the final demand figures. These assumptions may affect the accuracy of the estimates and thus are clearly stated for the reader's review and consideration.

\subsubsection{Resident Demand Analysis}

The resident demand analysis was developed using the NGF (1993) State Participation Model. This model multiplies the Rhode Island golf participation rate of 10.8 percent times the total population over the age of 12 to get an estimate of the total number of golfers in the market area. The estimated number of golfers is then multiplied by the NGF's (1993) average annual public rounds per golfer figure of 14.2. The resulting number is the estimated resident demand for public golf rounds in the market area. Table 5.5 shows the results of the resident demand analysis for the market area. This table was developed using 1990 Census information as the base line data for the analysis. 
TABLE 5.5 - Resident Demand Analysis

\begin{tabular}{lr}
\hline \multicolumn{1}{c}{ PLACE } & \multicolumn{1}{c}{1990} \\
\hline Washington County & 61,598 \\
Kent County & 90,200 \\
Newport County* & 47,501 \\
Bristol County* & 20,821 \\
Providence County* & 50,987 \\
Southeast CT & 5,570 \\
1990 Census Total & 276,677 \\
Background Growth (3\% annual) & 53,689 \\
1995 Estimated 12+ Population & 330,366 \\
NGF RI Participation Rate & $10.8 \%$ \\
Estimated \# Market Area Golfers & 35,679 \\
Avg. \# Annual Public Rounds Per Golfer & 14.2 \\
Estimated Market Demand Potential for Public & 506,641 \\
Rounds & \\
\hline \hline
\end{tabular}
Sources: U.S. Census, 1991.

R.I. Division of Planning, Housing Data Base, 1990.

NGF, Market Analysis for Newport Golf Club, 1993.

* Market area only covers portion of the county.

The resident market demand analysis using the State Participation Model leads to a 1995 estimated demand potential of 506,641 public golf rounds for the market area. Consistent with the finding of the demographic overview section of this chapter the county/town population figures were projected three percent a year during the period 1990 to 1995. 


\subsubsection{Tourist Demand Analysis}

The tourist demand figures were calculated in Tables 5.6A, 5.6B and 5.7 using the NGF (1993) Tourist Participation Model. This model assumes that 11.9 percent of the United State's population over the age of 12 plays golf, and that traveling golfers average .489 rounds of golf per day of a trip (NGF, 1993). Ten percent of all visiting tourist were assumed to be children under the age of 12 and thus were excluded from the figures (NGF, 1993). The percent of tourist visiting Washington County during the golf season was assumed to be 65 percent of the annual totals (NGF, 1993).

The tourism figures for South County were developed by Professor Timothy Tyrrell (1995), of the Department of Resource Economic's, Office of Travel, Tourism and Recreation at the University of Rhode Island. Tyrrell estimates that there are 5 to 10 million tourist visitor days in South County. A large portion of these visitor days are pass-through trips which typically do not include golf in their range of activities. Approximately 3 to 5 million of these visitor days included visits with overnight accommodations. It is this category of tourist which the NGF Tourism Participation Model attempts to focus on (Tyrell, 1995). To get a more complete picture the tourist demand calculation will be presented with both the high and low range tourists figures.

The Newport Tourism figures were developed by the NGF (1993) and are included in the analysis in order to get a more accurate demand figure for the whole market area. It is anticipated however that the proposed URI golf course will not draw a significant number of tourist golfers from Newport County. Rather, this analysis assumes that the proposed Newport National Golf Courses (which is further 
along in the development process and more conveniently located) will absorb the excess market demand created by Newport County tourists.

TABLE 5.6A - South County Tourist Demand Analysis, Low Estimate

\begin{tabular}{lc}
\hline \multicolumn{1}{c}{ Description } & Calculation \\
\hline Estimated \# of Washington Cty. Visitors Days & $3,000,000$ \\
Minus 10\% - Children Under Age of 12 & $(300,000)$ \\
Revised \# of Washington Cty. Visitors & $2,700,000$ \\
Percent Visiting During Golf Season & $65 \%$ \\
Revised \# of Washington Cty. Visitors & $1,755,000$ \\
National Participation Rate & $11.9 \%$ \\
Estimated \# of Washington Cty Tourist Golfers & 208,845 \\
Estimated \# Rounds Per Trip & .489 \\
Estimated \# Tourist Public Golf Rounds Demand for Wash- & 102,125 \\
ington County &. \\
Sources: NGF, Newport Golf Club Market Analysis, 1993. & \\
$\quad$ Rhode Island Visitors Study, 1994.
\end{tabular}

TABLE 5.6B - South County Tourist Demand Analysis, High Estimate

\begin{tabular}{lc}
\hline \multicolumn{1}{c}{ Description } & Calculation \\
\hline Estimated \# of Washington Cty. Visitors Days & $5,000,000$ \\
Minus $10 \%$ - Children Under Age of 12 & $(500,000)$ \\
Revised \# of Washington Cty. Visitors & $4,500,000$ \\
Percent Visiting During Golf Season & $65 \%$ \\
Revised \# of Washington Cty. Visitors & $2,925,000$ \\
National Participation Rate & $11.9 \%$ \\
Estimated \# of Washington Cty Tourist Golfers & 348,075 \\
Estimated \# Rounds Per Trip & .489 \\
Estimated \# Tourist Public Golf Rounds Demand for Wash- & 170,209 \\
ington County & \\
Sources: NGF, Newport Golf Club Market Analysis, 1993. & \\
$\quad$ Rhode Island Visitors Study, 1994.
\end{tabular}


TABLE 5.7 - Newport County Tourist Demand Analysis

\begin{tabular}{lc}
\hline \multicolumn{1}{c}{ Description } & Calculation \\
\hline Estimated \# of Newport Cty. Visitors Days & $7,500,000$ \\
Minus $10 \%$ - Children Under Age of 12 & $(750,000)$ \\
Revised \# of Newport Cty. Visitors & $6,750,000$ \\
Percent Visiting During Golf Season & $65 \%$ \\
Revised \# of Newport Cty. Visitors & $4,387,500$ \\
National Participation Rate & $11.9 \%$ \\
Estimated \# of Newport Cty Tourist Golfers & 522,112 \\
Estimated \# Rounds Per Trip & .489 \\
Estimated \# Tourist Public Golf Rounds Demand for New- & 255,312 \\
port County & \\
Sources: NGF, Newport Golf Club Market Analysis, 1993. & \\
$\quad$ Rhode Island Visitors Study, 1994.
\end{tabular}

The Washington County tourist demand calculations indicates a 1995 estimated potential demand between 102,125 and 170,209 public golf rounds for the market area. It is important to note that Tyrrell's tourism numbers, while they are the most current available data, are only rough estimates developed using a sales tax revenue model (not actual headcounts). Tyrrell however considers the 3 to 5 million visitor day range to be conservative estimate.

The Newport County tourist demand calculation indicates a 1995 estimated potential demand of 255,313 . The impact of these Newport tourist on the proposed URI golf course is assumed to be insignificant because of its locational disadvantage. An appropriate adjustment will be made during the market share calculation. 


\subsubsection{Student, Staff, Faculty \& Alumni Demand Analysis}

The student, staff, faculty and alumni demand figures for URI are analyzed in Table 5.8 using the NGF's (1993) Demographic Profile of all Golfers. In addition, the following assumptions were made in order to arrive at the demand figures:

a. Student population figures include only matriculating students attending classes at the Kingston Campus.

b. Ninety-five percent of all "out-of-state" students were assumed to live in residences outside the market area. Thus, they are a net increase to the population of the market area during the school year.

c. Forty percent of all "in-state" students were assumed to live outside the market area (Lawrence, 1995). The other 60 percent because they live in the market area were assumed to be included in the census figures.

d. Students were assumed to have a higher golf participation rate because of their young age profiles.

e. Average annual rounds of play (or frequency of play) for students was reduced from 14.2 to 10.0 because the majority of students are not oncampus during the peak play months of June, July and August.

e. Faculty because of their educational level and income profile (average annual salary of $\$ 57,400$ ) were assumed to have a higher golf participation rate (Lawrence, 1994-95).

f. No information was available through the University sources regarding the number of alumni who visit the campus annually. A lump sum figure of 35,000 visits was assumed. Consistent with the NGF national participation rate, it was assumed that 11.9 percent of these alumni were golfers. Each alumni golfer was assumed to have "frequency of play" characteristics similar to a visiting tourist (.489 per day). 
Table 5.8 - URI Students, Staff, Faculty and Alumni Demand Analysis

\begin{tabular}{|c|c|c|c|c|c|c|c|c|}
\hline Description & Totals & $\begin{array}{c}\%{ }^{* \star} \\
\text { Living Outside } \\
\text { Market Area }\end{array}$ & $\begin{array}{c}\text { Net } \\
\text { Impact On } \\
\text { Market Area }\end{array}$ & $\begin{array}{c}\text { Golf } \\
\text { Partic. } \\
\text { Rate }\end{array}$ & $\begin{array}{c}\text { Estim. } \\
\text { No. } \\
\text { Golfers }\end{array}$ & $\begin{array}{l}\text { Avg. } \\
\text { Yr. } \\
\text { Play }\end{array}$ & $\begin{array}{l}\text { Estim. } \\
\text { No. Yr. } \\
\text { Rounds }\end{array}$ & $\begin{array}{c}\text { Total } \\
\text { Rounds } \\
\text { Group }\end{array}$ \\
\hline \multicolumn{9}{|l|}{ Students" } \\
\hline Undergraduate In-state & 5,249 & 0.40 & 2,100 & 0.119 & 250 & 10 & 2,499 & \\
\hline Undergraduate Out-of-State & 4,019 & 0.95 & 3,818 & 0.119 & 454 & 10 & 4,543 & \\
\hline Graduate In-state & 1,259 & 0.40 & 504 & 0.119 & 60 & 10 & 599 & \\
\hline Graduate Out-of-State & 934 & 0.95 & $\underline{887}$ & 0.119 & 106 & 10 & 1,056 & \\
\hline Student Subtotal & 11,461 & & $7, \overline{309}$ & & 870 & & $\overline{8,697}$ & 8,697 \\
\hline Staff & 1,769 & 0.3 & $\underline{531}$ & 0.108 & $\underline{57}$ & 14.2 & $\underline{814}$ & 814 \\
\hline Faculty & $\underline{731}$ & 0.3 & $\underline{219}$ & 0.15 & $\underline{33}$ & 14.2 & $\underline{467}$ & 467 \\
\hline Alumni Visits & 35,000 & NA & 35,000 & 0.119 & 4,165 & 0.489 & 2,037 & 2,037 \\
\hline & & & & & & & & 12,015 \\
\hline
\end{tabular}

Sources: University of Phode Island Fact Book, 1994-95. NGF, Newport Golf Club Market Analysis, 1993.

* Includes only matriculating students attending the Kingston Campus.

** Estimates by author based on discussion with URI, Office of Institutional Research. Any student living inside the market area was assummed to be included in Census figures.

The student, staff, faculty and alumni demand calculation indicates a 1995 estimated demand potential of 12,015 annual public golf rounds. The majority of these URI golf rounds will be played by students $(8,697)$ and visiting alumni $(2,037)$. It is anticipated that staff (814) and faculty (467) rounds will accounting for only 11 percent of the total demand.

\subsection{Market Demand Summary}

The three previous sections of this chapter have provided estimates for the number of public golf rounds for the three categories of golfers within the market area. The total market potential is summarized in Table 5.9. 
Table 5.9 - Market Demand Summary, 1995

\begin{tabular}{lll}
\hline Category & Golfers & Rounds \\
\hline Residents & 35,679 & 506,641 \\
Tourist & & \\
- Washington County, Low Range & 208,845 & 102,125 \\
- Washington County, High Range & 348,075 & 170,209 \\
- Newport County & 522,112 & 255,312 \\
Student, Staff, Faculty \& Alumni & $\underline{5,125}$ & $\underline{12,015}$ \\
Total 1 (Low Range) & 771,761 & 876,093 \\
Total 2 (High Range) & 910,991 & 944,177 \\
\hline
\end{tabular}

Table 5.9 shows that the potential 1995 demand will vary between 876,093 to 944,177 public rounds of golf within the market area. This figure incorporates residents, visiting tourists, and URI students, staff, faculty and alumni demand figures. Given the conservative nature of Tyrrell's tourism figures, I feel that the larger of the two figures is a more accurate estimate for the market area. This figure however is meaningless without a better understanding of the supply side of the market area.

\subsection{Market Supply Analysis}

No market analysis is complete without an inventory of the existing golf courses which will compete with the proposed project. It is also important to have an understanding of the future changes within the market area such as courses which are being planned, constructed or closed (NGF, 1993). Where possible, detailed information regarding course quality, fees, and level of play was also collected in order to get a thorough understanding of the competition. The results of the survey are summarized below in Table 5.10. 
Teble 5.10 - Inventory of Existing and Planned Market Aree Golf Courses

\begin{tabular}{|c|c|c|c|c|c|c|c|c|c|c|c|c|c|}
\hline Course Name & City & Type & $\begin{array}{l}\text { Yr. } \\
\text { Built }\end{array}$ & Architect & $\begin{array}{l}\text { Annual } \\
\text { Rounds }\end{array}$ & $\begin{array}{l}\text { X Nine } \\
\text { Hole Play }\end{array}$ & $\begin{array}{l}\text { Weakend } \\
\text { 18hole }\end{array}$ & $\begin{array}{l}\text { Weakday } \\
\text { 18thole }\end{array}$ & $\begin{array}{l}\text { Nine } \\
\text { Hole }\end{array}$ & $\begin{array}{c}\text { Mens: } \\
\text { Reg. Yd. }\end{array}$ & Par & $\begin{array}{l}\text { Siope } \\
\text { Rating }\end{array}$ & $\begin{array}{c}\text { NGF } \\
\text { Maint Pating } \\
\end{array}$ \\
\hline \multicolumn{14}{|l|}{ Primery Competition } \\
\hline No. Kingstown Munic." & Davisville & Mu-18 & 1900 & Waiter I. Johnson & 50,000 & $30 x$ & $\$ 23.00$ & $\$ 21.00$ & $\$ 13.00$ & 5,848 & 70 & 115 & above avg. \\
\hline Exeter C.C.* & Exeter & DF-18 & 1969 & Geottrey Comish & 42,000 & $30 \%$ & 526.00 & $\$ 21.00$ & $\$ 12.00$ & 6,390 & 72 & 118 & above avg. \\
\hline${ }_{8}-\mathrm{z}$ & $\alpha \ldots$ & 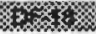 & 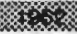 & $x_{m}$ & mon & 㬎 & 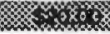 & (x) & mox & (x) & 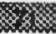 & 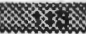 & W \\
\hline Pichmond C.C." & Richmond & DF-18 & 1992 & & 42,000 & & $\$ 29.00$ & $\$ 24.00$ & $\$ 15.00$ & 6,826 & 71 & & \\
\hline 6 & W & xis & & Kn & sing & mats & s. & \% & 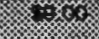 & (x) & 䇣 & & x. \\
\hline K & 怼 & - & 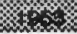 & 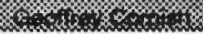 & 好好 & 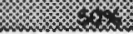 & 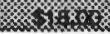 & 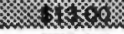 & & 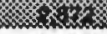 & & 玹 & Win \\
\hline Boulder Hill* & Hope Valley & DF-18 & 1995 & Trip Davis & 40,000 & (w/cart) & $\$ 45.00$ & 536.00 & & 6,600 & 72 & & \\
\hline son & mo & $8 \%$ & 2 & & -6 & - & K & 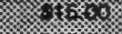 & ; & sick & m & 6 & sing \\
\hline 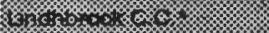 & (1 & 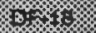 & & & 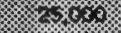 & & 1. & 16x r & & z. & & & \\
\hline Ka & 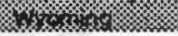 & 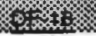 & & & \%ors & & 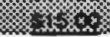 & 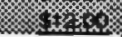 & 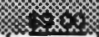 & 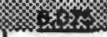 & 2 & & \\
\hline \multicolumn{2}{|c|}{ SUBTOTAL PRIMARY COMPETITION } & 144 & 1962 & & 349,000 & $39 \times 4[$ & 524.57 & 520.57 & $\int \$ 11.57$ & 6,258 & 71 & & \\
\hline Secondary Compotition & & & & & & \multicolumn{8}{|c|}{ (Avg. for 18-Hole Courses Only) } \\
\hline \multirow{3}{*}{$\begin{array}{l}\text { Green Valley C.C. } \\
\text { (n) }\end{array}$} & Portsmouth & DF-18 & 1965 & Manuel Raposa & 50,000 & $35 \%$ & $\$ 27.00$ & $\$ 22.00$ & $\$ 15.00$ & 6,674 & 70 & 120 & average \\
\hline & 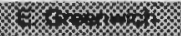 & m & (1) & xys & 3 & & & & 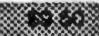 & 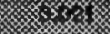 & 安 & & . \\
\hline & 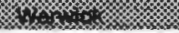 & 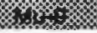 & x.m. & x. & $-2 x+3$ & - & & & 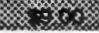 & 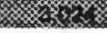 & 2 & & \\
\hline \multirow{2}{*}{$\begin{array}{l}\text { Winnapaug G.C." } \\
\text {. }\end{array}$} & Westerly & DF-18 & 1920 & Doneld Roess & 35,000 & & $\$ 28.00$ & 522.00 & $\$ 14.00$ & 6,386 & 72 & & \\
\hline & 1) & 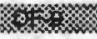 & 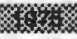 & & 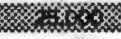 & & 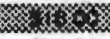 & (m) & 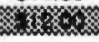 & 2 & 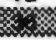 & 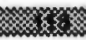 & \\
\hline \multirow{4}{*}{$\begin{array}{l}\text { Newport C.C. } \\
\text { Monteup C.C. } \\
\text { Wanumetonomy C.C. } \\
\text { Pocesset C.C. }\end{array}$} & Newport & PE-18 & 1928 & Donald Ross & 1,000 & & $\$ 75.00$ & $\$ 75.00$ & & & & & excellent \\
\hline & Portsmousth & $D F=18$ & 1823 & unknown & 50,000 & & $\$ 0.00$ & $\$ \$ 0.00$ & $\$ 17.00$ & 6,236 & 71 & 123 & excedlent \\
\hline & Middletown & PN-18 & 1920 & Seth Raynor & 5,000 & (W/cart) & $\$ 25.00$ & $\$ 05.00$ & & 6,162 & 70 & 117 & sowe avg. \\
\hline & Portamouth & DF-9 & 1960 & unknown & 30,000 & $25 \%$ & $\$ 18.00$ & $\$ 15.00$ & $\$ 8.00$ & 2,705 & 34 & & unknown \\
\hline \multirow{3}{*}{$\begin{array}{l}\text { Brisid G.C. } \\
\text { Midville C.C. }\end{array}$} & Bristal & $D F=0$ & & unknown & 25,000 & $60 x$ & $\$ 9 . \infty$ & $\$ 9.00$ & $\$ 8.00$ & 3,025 & 36 & & unknown \\
\hline & w. Warwick & $D F-9$ & 1862 & unknown & 40,000 & $50 \%$ & $\$ 20.00$ & $\$ 17.00$ & $\$ 11.00$ & 2.970 & 38 & & excellent \\
\hline & 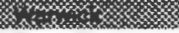 & 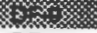 & & 纹 & $x$ & & Xnom & $2 x$ & $x$ & 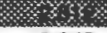 & & & \\
\hline \multirow{2}{*}{$\begin{array}{l}\text { Craneton C.C." } \\
\text { Foster Country Club }\end{array}$} & Cransion & DF-18 & 1974 & Goolfrey Comish & 37,000 & $50 \%$ & $\$ 27.00$ & $\$ 20.00$ & $\$ 17.00$ & 6,242 & 71 & 117 & aboveavg. \\
\hline & Foster & DF-18 & & & 35,000 & & $\$ 20.00$ & $\$ 18.00$ & $\$ 12.00$ & 6,187 & 72 & & \\
\hline \multirow{2}{*}{$\gamma_{1}$} & - & 40 & so & & 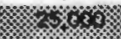 & & 14 & $6 \%$ & 26 & 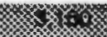 & 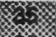 & & \\
\hline & & $\alpha$ & & & 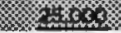 & & ros & 学 & 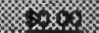 & 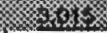 & 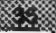 & & \\
\hline \multicolumn{2}{|c|}{ SUBTOTAL SECONDARY COMPETITION } & 207 & 1951 & & 488,000 & $44 \times[$ & $\$ 22.00$ & $\$ 18.87$ & $\int \$ 11.73$ & 6,311 & 71 & & \\
\hline \multicolumn{2}{|c|}{ TOTAL ALL EXISTING COURSES } & 351 & 1956 & & 837,000 & $42 \%$ & & & & & & & \\
\hline
\end{tabular}

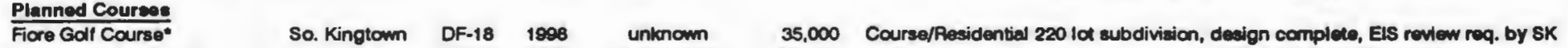
Newport Netional G.C. Newport DF-18 1997 Author Hills 50,000 Course Designed, contracts in place, permitting \& finencing problems SUBTOTAL PLANNED COURSES TOTALS PLANNED + EXISTING COURES 387

Sources: NGF, Newpot Golf Club Market Ana yais, 1003.

"Planned Courses" information was developed through personel Interviews by author with all Town Planners within the market area.

- Assurnes course will compete for South County tourist golfers.

The detailed market survey uncovered a total of 26 existing golf courses within

the market area. The operating structure of these courses is as follows: 22 daily fee courses, two municipal courses, and three private courses. There are a total of 360 available holes of golf in the market area: 12 courses in the 9-hole format, and 14 courses in 18-hole format. These existing 26 courses currently supply the market area with an estimated 837,000 annual public golf rounds. 
Ten of these existing golf courses because of their geographic location (10 miles or less) and fee structure are considered primary competition to the proposed URI golf course. These courses are listed separately at the top of Table 5.10.

The average year of construction for all the courses within the survey is 1956 . Fourteen of the courses were constructed prior to 1970, three courses were constructed in the 1970's, and only two courses have been constructed in the 1990's. It is important to note that these two new courses are located within the primary market area referenced above. The overall lack of recent golf course development tends to favor the potential of a new public golf course built to modern design standards (NGF, 1993).

Information regarding course architects is incomplete. A few of the courses were designed by notable golf course architects such as Donald Ross and Seth Raynor. With the exception of Boulder Hills and Richmond C.C., accredited modern golf course designers and builders have not been predominate in the area (NGF, 1993). The average length for men's regulation play on the 18 -hole courses in the survey is 6,284 yards. A NGF (1993) review of the market area's public golf courses offered the following additional design related comments:

"Greens are not constructed to USGA standards."

"Elevated greens and tees are not the standard and in most cases, greens are at fairway level in the front and pushed up slightly at the back."

"Irrigation systems of public courses are antiquated quick coupler systems requiring manual labor.. Many of the courses do not have irrigation for their fairways... The result is that irrigation systems cannot provide the kind of course coverage necessary for maintaining high quality golf facilities." 
"Tee-to-green cart paths are not found on any of the area public courses.. which limits play during rainy periods"

"The quality of the area courses is below average due to the void of courses built in the market area over the last 30 years..."

A review of the fee structure for the courses in the market area found the following: an average 18 -hole weekend rate of $\$ 23.28$, an average 18-hole weekday rate of $\$ 19.67$, and an average weekday 9 -hole rate of $\$ 11.65$. These averages exclude the Wanumetonomy and Newport C.C. rates which were considered unusually high fees for the public golf market.

The inventory also found two 18-hole golf courses which are in the planning and design phase. Both of these planned courses are significantly further along in the development process then the proposed URI course. It is anticipated that one of the proposed courses will be located in the primary market area, within 10 miles of the proposed URI course. The level of background information regarding theses courses is sketchy making it difficult to predict when, and if, they will be built. A worst case scenario suggest that both courses will be built prior to completion of the URI golf course. It is anticipated that these two courses will supply 85,000 annual public golf rounds. The total supply figure for the market area's 26 existing golf courses and the two planned courses is estimated at 922,000 rounds of public golf.

\subsection{Estimated Market Potential}

The total market demand and supply side figures as previously established in other sections of this report are summarized in Table 5.11. By comparing these two figures the estimated market potential can now be established. 
Table 5.11 - Estimated Market Potential

\begin{tabular}{lr}
\hline \multicolumn{1}{c}{ Description } & Figures \\
\hline Market Demand Summary (Table 5.9) & 944,177 \\
Market Supply Inventory (Table 5.10) & 922,000 \\
Estimated Market Potential & 22,177 \\
\hline
\end{tabular}

The results of Table 5.11 indicate that there is only 22,177 surplus public golf rounds in the market area. This suggests that there is only limited excess market demand. This relatively small figure, ( $2 \%$ of the total market demand figure) is not enough to support a new daily fee course which typically requires approximately 40,000 rounds. This also suggests that the golf market may be in a state of equilibrium with the addition of the two planned courses.

This finding has negative consequences on the overall feasibility of the proposed URI golf course. With limited surplus demand in the market area the proposed URI golf course would have to draw play away from other courses in order to be successful. Prior to drawing any final conclusions, however, it is important to estimate the potential market share for the project.

\subsection{Estimated Market Share}

The findings of the "Market Supply Analysis" in Section 5.5 suggest that the market area may be ripe for the development of new golf course built to modern design and irrigation standards. To test this argument I have developed a simple model which attempts to estimate a realistic market share for the project. 
This model assumes that the proposed course will require approximately 40,000 annual rounds to operate successfully. It uses the demand summary figures from Table 5.9 as its baseline data. The market share estimates for the "residents" rounds is assumed to be 3.3 percent. This percentage is derived by dividing one over 28 , the total number of existing and planned courses. The market share estimate for South County "tourist rounds" is 8.3 percent, which is one divided by the number of courses within the market area that could potentially compete for the tourist play (1/12). These 12 courses are identified out in Table 5.10. The market share estimate for the Newport County "tourist rounds" is assumed to be zero because of the reasons referenced earlier in this report. The market share estimate for the URI rounds is assumed to be 90 percent.

Field research and a review of the NGF (1993) Golf Market Analysis for a Proposed Newport Golf Club suggests that there are at least 12 golf courses in the market area below the anticipated quality of the proposed URI course (see highlighted courses in Table 5.10). The proposed URI golf course should draw market share away from these inferior golf courses. This assumes that the proposed URI golf course will operate under a comparable fee structure to the 12 inferior courses. How much market share each course will lose is difficult to predict. 
Table 5.12A - Market Share Estimate, Best Case Scenario

\begin{tabular}{lrcr}
\hline Group & Total Rounds & Market Share & Captured Rounds \\
\hline Residents & 506,641 & $3.3 \%$ & 16,719 \\
Tourist & & & \\
- South County & 170,209 & $8.3 \%$ & 14,127 \\
- Newport Cty & 255,312 & $0 \%$ & 0 \\
URI & 12,015 & $90 \%$ & 10,814 \\
Total & 944,177 & $4.4 \%$ & 41,660 \\
\hline
\end{tabular}

The market share estimates developed in Table 5.12A suggests that the proposed URI golf course could potentially capture 41,660 public golf rounds from the market area. On the surface the market share estimates which produce the total "captured rounds" figure look fairly modest and attainable. This figure however should be considered a "best case scenario" which could only be achieved with a high quality, professionally managed and maintained course, which was aggressively marketed and promoted. To understand why, we need to summarize the significant findings from this chapter:

a. The estimated market potential for this area is limited. The is not enough excess market demand to support a new daily fee course.

b. In general terms, the overall quality of the existing 26 golf courses in the market area is below average. While there are notable exceptions, the majority of the courses are outdated and do not meet modern design standards.

c. This fact favors the potential development of a new public golf course which would probable draw play away from existing poorer quality course with similar fee structures.

d. There are probably two other courses in the market area which are currently at various stages within the development process. It is highly 
likely that these courses will enter the market ahead of the proposed URI course.

e. The URI course will be competing for market share in a more competitive environment with three modern courses of similar, or better quality, located within 10 miles of its site.

In addition to these market considerations the author also has serious reservations about whether the University has the administrative and financial resources to maintain and market the proposed course in a competitive "private sector" market. The University is a large, bureaucratic institution whose organizational structure does not lend itself to the quick decisions and flexibility required to compete with the private sector. Moreover, according to the NGF (1993) it takes up to five years or more for facility to reach its playing capacity during which time significant operating losses are often incurred. Given URI's perennial fiscal problems it seems unrealistic to assume that the University will have the financial resources to market and maintain a high quality golf course, particularly during the lean start-up years.

When you combine the market consideration with the above referenced management concerns it seems unlikely that the proposed URI golf course will reach the market share estimate presented in Table 5.12A. A more conservative market share estimate is presented in Table 5.12B. 
Table 5.12B - Market Share Estimate, Worst Case Scenario

\begin{tabular}{|c|c|c|c|}
\hline Group & Total Rounds & Market Share & Captured Rounds \\
\hline Residents & 506,641 & $2 \%$ & 10,132 \\
\hline \multicolumn{4}{|l|}{ Tourist } \\
\hline - South County & 170,209 & $2.4 \%$ & 4,055 \\
\hline - Newport Cty & 255,312 & $0 \%$ & 0 \\
\hline URI & 12,015 & $90 \%$ & 10,813 \\
\hline Total & 944,177 & $2 \%$ & 25,000 \\
\hline
\end{tabular}

The more conservative market share estimates developed in Table 5.12B suggests that the proposed URI golf course could potentially capture 25,000 public golf rounds from the market area. This figure should be considered a "worst case scenario" which reflects the market assumptions and management concerns referenced earlier.

Taken together, the two market share estimates contained in Tables 5.12A and 5.12B form a potential high and low operating range for the proposed project. In my opinion neither of the two range figures are likely outcomes. I anticipate that the actual market share figure will be more in line with the middle of the specified range. A more realistic market share estimate for the proposed course given the current market conditions would be 33,000 rounds. 


\subsection{References}

National Golf Foundation. 1989. Guidelines for Planning and Developing a Public Golf Course. Jupiter, Florida. National Golf Foundation.

National Golf Foundation. 1991. Golf Consumer Profile.Jupiter, Florida National Golf Foundation.

National Golf Foundation. 1993. Golf Market Analysis for a Proposed Newport Golf Club. Jupiter, Florida. National Golf Foundation.

Division of Planning. 1989. Land Use 2010: State Land use Policies and Plan. Report No. 64. Providence, RI. Rhode Island Department of Administration.

Division of Planning. 1990. Housing Data Base. Report No. 67. Providence, RI. Rhode Island Department of Administration.

Personal Interview. Timothy J. Tyrrell. University of Rhode Island, Department of Resource Economics, Office of Travel, Tourism and Recreation. July 6, 1995.

Personal Interview. Barry Devine. University of Rhode Island, PhD Candidate. July 21, 1995. 
CHAPTER SIX - FINANCIAL ASSESSMENT 


\subsection{Introduction}

The purpose of this section is to estimate the financial returns and potential risks associated with the proposed project. Chapter six is divided into five sections. First, the financial goals, or investment backed expectations for the proposed project are identified. Second, a program budget is developed which estimates the total cost of the proposed project. This is followed by a proforma analysis which projects the operating expenses and revenues for the first five years of operations. Fourth, the results of the proforma projections are analyzed and final conclusions are offered regrading the financial feasibility of the proposed course. The chapter ends with an overview of the author's assumptions regarding project financing for the proposed golf course.

\subsection{Financial Objectives}

Discussions with project proponents and a key University administrator (Kermes, 1995) during the course of this study suggest that no definitive financial expectations have been established for the project as of this writing. The project proposal written by Casagrande and Devine (1993) includes the following objective, "To build a financial asset for the URI capable of generating income for University programs". The proposal does not clearly define what constitutes a "financial asset" and how much income it should generate. According to Muirhead and Rando (1994) establishing a set of clear investment expectations is crucial because "projects borne 
on pure optimism and trial and error can not even hope to find a source of financing during tight economic times."

Without a clear understanding of the basic financial objectives it is extremely difficult to objectively determine whether the golf course should be built. For the sake of this analysis I assumed that the proposed course must at a minimum break even (after revenues stabilize), in order for the University to even consider proceeding with the project.

It is also anticipated that developing the proposed golf course will also have a number of ancillary benefits which inherently are not factored into a proforma analysis. These ancillary benefits will be identify and discussed more thoroughly in Chapter 7. Trying to quantify the impact, or dollar value, of these ancillary benefits is difficult and beyond the scope of this study. It is extremely important, however, for the University to identify and analyze these benefits in order to ensure that an educated decision is made regarding the overall feasibility of the proposed course.

\subsection{Program Budget}

A program budget is proposed for the entire cost to develop the proposed project (see Table 6.1). This program budget is broken down into three major components. First, the construction budget which includes the hard costs to build the facility is estimated to cost $\$ 2,533,000$. Second, the owner-furnished equipment and furnishings which are required to operate and maintain the facility is estimated to cost $\$ 175,000$. Third, soft costs such as design, construction, and professional fees, 
and "grow-in" costs are estimated to cost $\$ 522,640$. These three cost components

total to a final program budget of $\$ 3,392,172$.

Table 6.1 - Program Budget

\section{Construction Budget}

Target Range Construction

Putting Course Construction

Clubhouse Facility

Classroom Facility w/ Lab

Maintenance Facility

Project Landscaping

Access Road

Customer/Staff Parking Lot

Sewer Extension

Extend Utilities

Irragation Supply Structures

Back Nine Rock Allowance

Wetlands remed. \& misc. site clean-up

Golf Course Construction

- Front Nine - "Links Course"

- Back Nine - "Park Land Course"

- Three Hole Research Course

- Course signage, shelters, \& washiers

Subtotal Construction Cost

Owner Equipment \& Furnishing

Maint. Equip., Tools, Veh., Supplies

Office Equip., Furnishings, Computers

Misc. Operating Equipment

Subtotal Owner Equip. \& Furnishing

\section{Consulting \& General Conditions}

Architectual / Engineering Services

Surveying

Construction Management Services

Legal Fees \& Permitting

Construction Loan (Carry Cost)

Long Term Financing

Superfund Clean-up

Operations during "grow-in" phase

Subtotal Consulting \& G.C.

Subtotal Program Budget

Owner Contigency Fund 5\%

TOTAL PROGRAM BUDGET*
$\$ 120,000 \quad$ Lump sum figure

$\$ 75,000$ Lump sum figure

$\$ 78,000 \quad 1200$ sf bld. @ \$65 sf

$\$ 45,000$ Renovate existing kennal facility

$\$ 150,000$ Assume 6,000 sf @ \$25 si

$\$ 125,000$ Clubhouse and course

$\$ 15,000$ Assume 24' wide road @ 900 LF

$\$ 15,000$ Assume 90 spaces @ 350 sf ea.

$\$ 135,000 \quad 4,500$ LF @ \$30 Lf

$\$ 15,000$ Phone, electric, water etc.

$\$ 70,000$ Assume one per side @ $\$ 35,000$ ea.

$\$ 25,000$ Approx. $25 \%$ forested acreage classified "extremely stoney"

$\$ 50,000$ Clean up dump area \& remediate wetlands area.

Includes irrgation, tees, greens, bunkers, fairways \& course design

$\$ 630,0009$-Holes @ $\$ 70,000$ ea.

$\$ 720,000$ 9-Holes @ \$80,000 ea.

$\$ 240,000$ 3-Holes @ \$80,000 ea.

$\$ 25,000$

$\$ 2,533,000$

$\$ 125,000$

$\$ 30,000$

$\$ 20,000$

$\$ 175,000$

$\$ 75,990$

$\$ 25,000$

$\$ 126,650$

$\$ 45,000$

$\$ 0$

$\$ 0$

$\$ 0$

$\$ 250,000$

$\$ 522,640$

$\$ 3,230,640$

$\$ 161,532$

$\$ 3,392,172$
Assume 1/2 of NGF estimate due to low imput design

Range balls, clubs, buckets, uniforms etc.

Assume $3 \%$ of construction cost for design all auxcillary facilities Lump sum figure

Assume $5 \%$ of construction costs for construction adminstration.

Lump sum figure

Carrying cost included in price per hole figure above

Cost to issue/underwrite bonds carried in proforma analysis

Limited information, clean-up budget not established

Assummes reduced oper. staff for 1 year grow-in period

* Land cost assummed to be zero 
The program budget was developed using a start-up budget prepared by Devine and Casagrande (1994), NGF (1989) and Urban Land Institute (1994) literature, and my professional experience in the construction management industry. The estimate assumes that the project will be built in one phase which last approximately 18 months. The estimate also assumes that the course design and construction will be performed by professional consulting firms, not students, or faculty.

No land acquisition budget is carried for the proposed project because it is assumed that the University owns the proposed site outright. This should provide the University with a strong competitive advantage over other courses in the market area. According to the NGF (1989) the economics of a typical public golf course (in a good market) will support debt service on land as much as $\$ 4,000$ to $\$ 8,000$ per acre. It is likely however that this competitive advantage will be offset by the cost to remediate the Superfund site. No budget is included for the clean-up because a reliable figure can not be established until the EPA Remedial Investigation and Feasibility Study (RI/FS) is completed.

The per-hole budget figures used for the construction of the course are assumed to cover the costs: clearing and grubbing of the land, grading, irrigation and drainage systems, planting of trees, greens, tees, fairways, service roads, cart paths, builders profit and overhead, construction financing, and course design fees (Connery,1994). These budget figures are consistent with the range established for Class III courses by the Marshall Valuation Service. This is a document used in an 
appraisal of the Newport National Golf Club prepared by Golf Realty Advisors Inc. for Fleet Bank (Connery, 1994). A summary of cost per hole budget figures as established by the Marshall Valuation Services is presented in Table 6.2.

Table 6.2 - Cost Per Hole Budget Figures

\begin{tabular}{|c|c|c|}
\hline Class & Description & Cost Per Hole \\
\hline $\mathbf{I}$ & $\begin{array}{l}\text { Minimal quality, simply developed budget } \\
\text { course on open, natural or flat terrain; few } \\
\text { bunkers; small tees and greens. }\end{array}$ & $\begin{array}{l}\$ 36,000 \\
\text { to } \\
\$ 48,000\end{array}$ \\
\hline II & $\begin{array}{l}\text { Simply designed course on relatively flat } \\
\text { terrain; natural rough; few bunkers; small } \\
\text { built-up tees and greens; some small trees }\end{array}$ & $\begin{array}{l}\$ 49,000 \\
\text { to } \\
\$ 66,000\end{array}$ \\
\hline III & $\begin{array}{l}\text { Typical private club on undulating terrain; } \\
\text { bunkers at most greens; average elevated } \\
\text { tees and greens; some large trees moved in } \\
\text { or clearing of some wooded areas; driving } \\
\text { range. }\end{array}$ & $\begin{array}{l}\$ 67,000 \\
\text { to } \\
\$ 91,000\end{array}$ \\
\hline IV & $\begin{array}{l}\text { Championship course on good undulating } \\
\text { terrain; fairway and greens bunkered and } \\
\text { contoured; large trees and greens; large } \\
\text { transplanted trees; driving range; name } \\
\text { architect }\end{array}$ & $\begin{array}{l}\$ 92,000 \\
\text { to } \\
\$ 126,000\end{array}$ \\
\hline
\end{tabular}

The program budget assumes minimal funding for on site facilities. This includes a conservative 1,200 square foot clubhouse facility which will house the pro shop, snack bar, and administrative offices. The maintenance facility was programmed as a 6,000 square foot modular, metal skinned building which will be used to store power equipment, fertilizers, pesticides, and tools. It is anticipated that the existing dog kennel will be renovated into classroom and laboratory space. No 
money is programmed for a golf cart storage facility. On site parking will be limited to one 90-space lot which will service both staff and patrons. It was assumed that the University sewer line will be extended from Flagg Road to the site in order to mitigate the impact on the existing ground water contamination problem.

The NGF foundation estimates that a typical 18-hole public golf course requires approximately $\$ 250,000$ in start-up maintenance equipment, tools, vehicles and supplies. For the purpose of the proposed golf course, this figure is reduced by 50 percent based on the low input, low maintenance design guidelines established for the course.

The budget assumes a one year "grow-in" period at a cost of $\$ 250,000$ to allow the grass to mature properly. During this period there will be no revenues and the course will be managed and maintained by a reduced staff. It is important to note this "grow-in" period could be significantly reduced by using sod instead of hydro-seed planting techniques. The sod does however has a higher up front construction costs which would need to be evaluated against reduced "grow-in" costs.

The carrying cost associated with construction financing was assumed to be included in the cost per hole budget figures based on the Marshall Valuation Service breakdown referenced above. The underwriting fees associated with long term financing are accounted for within the proforma analysis. There will be a more thorough explanation of these costs in Section 6.5 of this chapter.

Finally a $\$ 25,000$ "rock allowance" was budgeted to cover the removal of rocks and ledge over one cubic yard in size. This was deemed necessary based on the 
findings of the soils analysis in Chapter Four and a field inspection of the proposed site.

\subsection{Proforma Analysis}

The first task in this section is to establish the projected rounds mix and fee schedule for the proposed course. The total number of rounds, together with the mix of rounds, is of critical importance when forecasting green fees revenues (Connery, 1994). The total rounds projected will be analyzed twice using the "worst case scenario" (Table 6.3A) and "best case scenario" (Table 6.3B) range established in Chapter Five. The methodology and assumptions made in each table are identical, except where specified. This analysis is developed based on a 9-month golf season and a daily fee operating structure with no private memberships.

The analysis also assumes that the course will take five years to reach full playing capacity (NGF, 1989). The playing capacity for year one is 62 percent, year two is 76 percent, year three 86 percent, year four 95 percent, year five is 100 percent. The mix (or distribution) of the rounds is assumed to be as follows: 18-hole weekday will be 50 percent of play, 18-hole weekend will be 30 percent of play, and 9-hole play will be 20 percent of play.

According to Connery (1994) the average daily fee golf course experiences cart utilization rates in the range of 30 to 75 percent depending on management policies and the topography of the course. It is anticipated that URI golf course will operate at the lower end of the range because of the large numbers of students using the course. This will be particularly true under the "worst case scenario" (Table 
6.3A) market share estimate because students make up such a large proportion of the total demand figure. Table $6.3 \mathrm{~B}$ has a slightly higher projected cart utilization rate of 40 percent because students are a smaller proportion of the "best case scenario" market share estimate.

Under the ancillary facilities category there are two other major revenue generators. The first is the target range which Devine and Casagrande (1994) estimate will sell 35,000 buckets in year one of operation. For the sake of this analysis this figure is assumed to be the full capacity, (or fifth year) estimate under a "best case scenario" profile. This assumes that the target range will operate at capacity rates similar to those estimated for the golf course above. The 35,000 bucket estimate was discounted 57 percent to 15,050 buckets to develop the full capacity "worst case scenario" profile.

The second ancillary revenue generator is the 18-hole putting course which Devine and Casagrande (1994) estimate will sell 24,000 rounds in year one. For the sake of this analysis this figure is also assumed to be the full capacity estimate under a "best case scenario" profile. Again this figure is discounted 57 percent to 10,320 putting course rounds to develop the full capacity "worst case scenario" profile.

Greens fees for the golf course are established at 1995 market rates based on the results of the golf course inventory conducted in Chapter Five. These fees are escalated over the five year period consistent with standards established in NGF (1989) literature. The target range and putting greens fees are taken from the startup budget prepared by Devine and Casagrande. The pro shop and food and beverage fees are per round expenditures based on national averages found in NGF (1989) literature. These figures are escalated three percent a year for inflation. 
Table 6.3A - Projected Rounds Mix and Fee Schedule (worst case scenario)

\section{Annual Rounds}

18-Hole Weekday (50\%)

18-Hole Weekend (30\%)

9-Hole (20\%)

Total Projected Rounds

Golf Cart Rounds

18-Holes (30\%)

9-Holes (30\%)

Total Golf Cart Rounds

Auxcillary Facilties

Target Range Buckets

Putting Course Rounds
Year 1 Year 2 Year 3 Year 4 Year 5

$\begin{array}{lllll}7,750 & 9,500 & 10,750 & 11,875 & .12,500\end{array}$

$\begin{array}{lllll}4,650 & 6,650 & 7,525 & 8,313 & 8,750\end{array}$

$\underline{3,100} \quad \underline{2,850} \quad \underline{3,225} \quad \underline{3,563} \quad \underline{3,750}$

$\begin{array}{lllll}15,500 & 19,000 & 21,500 & 23,750 & 25,000\end{array}$

$\begin{array}{lllll}3,720 & 4,845 & 5,483 & 6,056 & 6,375\end{array}$

$\begin{array}{rrrrr}\frac{930}{4,650} & 5,700 & 6,455 & \frac{968}{7,125} & \frac{1,125}{7,500}\end{array}$

$\begin{array}{lllll}9,331 & 11,438 & 12,943 & 14,298 & 15,050\end{array}$

$\begin{array}{lllll}6,398 & 7,843 & 8,875 & 9,804 & 10,320\end{array}$

\section{Proposed Fee Schedule}

Green Fees

18-Hole Weekday

18-Holes Weekend

9 Holes

Golf Cart Fees

18-Holes (per player)

9 Holes (per player)

$\begin{array}{lllll}\$ 20.00 & \$ 20.00 & \$ 21.50 & \$ 21.50 & \$ 23.00 \\ \$ 24.00 & \$ 24.00 & \$ 25.50 & \$ 25.50 & \$ 27.00 \\ \$ 12.00 & \$ 12.00 & \$ 13.50 & \$ 13.50 & \$ 15.00\end{array}$

$\$ 10.00 \quad \$ 10.00$

$\$ 10.50$

$\$ 10.50 \quad \$ 11.00$

$\$ 5.50 \quad \$ 5.50 \quad \$ 6.00$

$\$ 5.00 \quad \$ 5.00$

Departmental Revenue

Golf Shop (per round)

Food \& Beverage (per round)

$\$ 1.50$

$\$ 1.58$

$\$ 1.65$

$\$ 1.74$

$\$ 1.82$

$\$ 2.00$

$\$ 2.10$

$\$ 2.21$

$\$ 2.32$

$\$ 2.43$

$\$ 5.00$

$\$ 5.00$

$\$ 5.50$

$\$ 5.50$

$\$ 6.00$

Putting Course (per round)

$\$ 4.00$

$\$ 4.00$

$\$ 4.50$

$\$ 4.50$

$\$ 5.00$ 
Table 6.3B - Projected Rounds Mix and Fee Schedule (best case scenario)

\section{Annual Rounds}

18-Hole Weekday

18-Hole Weekend

9-Hole

Total Projected Rounds

\section{Golf Cart Rounds}

18-Holes (40\%)

9-Holes (40\%)

Total Golf Cart Rounds

\section{Auxcillary Facilties}

Target Range Buckets

Putting Course Rounds
Year 1 Year 2 Year 3 Year 4 Year 5

$\begin{array}{rrrrr}10,230 & 12,540 & 14,190 & 15,675 & 16,500 \\ 6,138 & 8,778 & 9,933 & 10,973 & 11,550 \\ 4,092 & \frac{3,762}{4,250} & \frac{4,257}{28,380} & \frac{4,703}{31,350} & 3 \frac{4,950}{33,000}\end{array}$

$$
\begin{array}{rrrrr}
6,547 & 8,527 & 9,649 & 10,659 & 11,220 \\
\frac{1,637}{8,184} & \frac{1,505}{10,032} & \frac{1,703}{11,352} & \frac{1,881}{12,540} & \frac{1,980}{13,200}
\end{array}
$$

$\begin{array}{lllll}16,058 & 19,684 & 22,274 & 24,605 & 25,900 \\ 11,011 & 13,498 & 15,274 & 16,872 & 17,760\end{array}$

\section{Proposed Fee Schedule}

Green Fees

18-Hole Weekday

18-Holes Weekend

9 Holes

Golf Cart Fees

18-Holes (per player)

9 Holes (per player)

Departmental Revenue

Golf Shop (per round)

Food \& Beverage (per round)

Target Range (per bucket)

Putting Course (per round)
$\$ 20.00 \quad \$ 20.00 \quad \$ 21.50$

$\$ 24.00 \quad \$ 24.00 \quad \$ 25.50$

$\$ 12.00 \quad \$ 12.00 \quad \$ 13.50$

$\$ 21.50$

$\$ 25.50$

$\$ 13.50$

$\$ 23.00$

$\$ 27.00$

$\$ 15.00$

$\$ 10.00$

$\$ 10.00$

$\$ 10.50$

$\$ 10.50$

$\$ 11.00$

$\$ 5.00$

$\$ 5.00$

$\$ 5.50$

$\$ 5.50$

$\$ 6.00$

$\$ 1.50$

$\$ 1.58$

$\$ 1.65$

$\$ 1.74$

$\$ 1.82$

$\$ 2.00$

$\$ 2.10$

$\$ 2.21$

$\$ 2.32$

$\$ 2.43$

$\$ 5.00$

$\$ 5.00$

$\$ 5.50$

$\$ 5.50$

$\$ 6.00$

$\$ 4.00$

$\$ 4.50$

$\$ 4.50$

$\$ 5.00$ 
The second task in this section is to develop the proforma projections. (see Tables 6.4A and 6.4B) More specifically, these two tables estimate the projected revenues and expenses for the proposed course over the first five years of operations. The revenue projections are relatively straight forward and are calculated by multiplying the number of projected rounds by the applicable fee (as established in Tables $6.3 \mathrm{~A}$ and $6.3 \mathrm{~B}$ ). For reasons which will be discussed more thoroughly in Section 6.5 , no revenue is projected from the sale of club memberships.

The projected costs and expenses are developed in the following manner. First, the Operational Expenses and Maintenance Expense are taken from a sample proforma prepared by the NGF(1989). These figures cover costs associated with operating and maintaining a golf course and include expenses such as salaries, wages, benefits, office supplies, course and building maintenance, all utilities, office supplies, accounting and legal expenses and insurance. In Table 6.4A these two line items are discounted 25 percent for the following reasons: First, it is anticipated that reduced play associated with the "worst case scenario" market share estimate will translate into reduced operating and maintenance expenses. Second, it is anticipated that the low-input design guidelines proposed by Casagrande and Devine (1994) will result in an additional 15 percent reduction in maintenance expenses. In Table 6.4B these two line items are discounted by 15 percent for the reduced maintenance expenses associated with the low-input design guidelines.

Golf cart expenses are assumed to be 35 percent of total cart revenue. This estimate is intended to apply regardless of whether carts are purchased or leased by the golf course (NGF, 1993). Marketing expenses under the "worst case scenario" market share estimate range from $\$ 10,000$ in year one, to $\$ 2,500$ in year five. 
Marketing expenses under the higher "best case scenario" range from $\$ 25,000$ in year one, to $\$ 6,250$ in year five. Consistent with the findings in Chapter Four and Five, it is anticipated that an aggressive marketing campaign will be required to reach the "best case scenario" market share estimate.

Based on discussions with key project proponents it is anticipated that the University will provide students, staff and faculty golfers with a discounted greens fee. (No allowance was made for alumni golfers). It is anticipated that this discount will be in the range of 40 percent which will have a dramatic effect on the project's projected revenue stream. The "URI Discounted Round Adjustment" line attempts to quantify the impact of this subsidy on the project. Under the "worst case scenario" market share estimate contained in Table 6.4A this group accounts for approximately 32 percent of the total rounds played. Therefore 32 percent of the annual greens fee revenue are discounted 40 percent to account for the subsidy. The impact on the "best case scenario" market share estimate is less severe because URI student, staff and faculty golfers only account for 26 percent of the total rounds played. Therefore 26 percent of the annual green fees revenues are discounted 40 percent to account for the subsidy.

The Replacement Reserve line item is an account established at the start of a project to offset the future cost to repair and replace the course facilities and equipment. No funds are set aside in year one. The year two figures equals one percent of the total projected revenues. In year three this figure will be increased to two percent were it will stay for the remainder of the projects lifecycle.

The annual departmental expenses are calculated in the following way. Direct expenses associated with operating the food and beverage operations were estimated 
to be 50 percent of the total food and beverage revenues. This estimate assumes self-operations and the largest expenses would be cost of goods sold (NGF, 1993). Direct expenses associated with operating the pro shop are estimated to be 72 percent of the total pro shop revenue. This estimate also assumes self-operations and the largest expenses would be cost of goods sold (NGF, 1993). The target range expenses are estimated to be 30 percent of the total range revenues, which includes annual range ball replacement costs. The putting course expenses are estimated to be 20 percent of total putting course revenues.

Table 6.4A - Proforma Projections (worst case scenario)

\section{Projected Revenues}

Club Memberships

Green Fees

Total Cart Fees

Target Range Fees

Putting Course Fees

Golf Shop Sales

Food \& Beverage Sales

Total Projected Revenues

\section{Projected Costs and Expenses:}

Operational Expenses

Maintenance Expenses

Golf Cart

Marketing

URI Discounted Rounds

Replacement Reserve

Departmental

Golf Shop

Target Range

Putting Course

Food \& Beverage

Total Facility Expenses

Net Operating Income

(Before Debt Service)

Less Annual Debt Servlce

Profit / Lose After Debt Service

Cummulative Deficit

\begin{tabular}{|c|c|c|c|c|}
\hline Year 1 & Year 2 & Year 3 & Year 4 & Year 5 \\
\hline$\$ 0$ & $\$ 0$ & $\$ 0$ & $\$ 0$ & $\$ 0$ \\
\hline$\$ 303,800$ & $\$ 383,800$ & $\$ 466,550$ & $\$ 515,375$ & $\$ 580,000$ \\
\hline$\$ 41,850$ & $\$ 52,725$ & $\$ 62,888$ & $\$ 69,469$ & $\$ 76,875$ \\
\hline$\$ 46,655$ & $\$ 57,190$ & $\$ 71,187$ & $\$ 78,636$ & $\$ 90,300$ \\
\hline$\$ 25,594$ & $\$ 31,373$ & $\$ 39,938$ & $\$ 44,118$ & $\$ 51,600$ \\
\hline$\$ 23,250$ & $\$ 30,020$ & $\$ 35,475$ & $\$ 41,325$ & $\$ 45,500$ \\
\hline$\$ 31,000$ & $\$ 39,900$ & $\$ 47,515$ & $\$ 55,100$ & $\$ 60,750$ \\
\hline$\$ \overline{472,149}$ & $\$ \overline{595,008}$ & $\$ \overline{723,552}$ & $\$ \overline{804,023}$ & $\$ \overline{905,025}$ \\
\hline$\$ 165,225$ & $\$ 173,486$ & $\$ 182,161$ & $\$ 191,269$ & $\$ 200,832$ \\
\hline$\$ 196,725$ & $\$ 206,561$ & $\$ 216,889$ & $\$ 227,734$ & $\$ 239,120$ \\
\hline$\$ 14,647$ & $\$ 18,454$ & $\$ 22,011$ & $\$ 24,314$ & $\$ 26,906$ \\
\hline$\$ 10,000$ & $\$ 7,500$ & $\$ 5,000$ & $\$ 2,500$ & $\$ 2,500$ \\
\hline$\$ 58,330$ & $\$ 73,690$ & $\$ 89,578$ & $\$ 98,952$ & $\$ 111,360$ \\
\hline$\$ 0$ & $\$ 5,950$ & $\$ 14,471$ & $\$ 16,080$ & $\$ 18,101$ \\
\hline$\$ 16,740$ & $\$ 21,614$ & $\$ 25,542$ & $\$ 29,754$ & $\$ 32,760$ \\
\hline$\$ 13,997$ & $\$ 17,157$ & $\$ 21,356$ & $\$ 23,591$ & $\$ 27,090$ \\
\hline$\$ 5,119$ & $\$ 6,275$ & $\$ 7,988$ & $\$ 8,824$ & $\$ 10,320$ \\
\hline$\$ 15,500$ & $\$ 19,950$ & $\$ 23,758$ & $\$ 27,550$ & $\$ 30,375$ \\
\hline$\$ 496,282$ & $\$ 550,637$ & $\$ 608,752$ & $\$ 650,567$ & $\$ 699,364$ \\
\hline$(\$ 24,134)$ & $\$ 44,371$ & $\$ 114,800$ & $\$ 153,456$ & $\$ 205,661$ \\
\hline$\$ 210,000$ & $\$ 210,000$ & $\$ 210,000$ & $\$ 210,000$ & $\$ 210,000$ \\
\hline$(\$ 234,134)$ & $(\$ 165,629)$ & $(\$ 95,200)$ & $(\$ 56,544)$ & $(\$ 4,339)$ \\
\hline$(\$ 234,134)$ & $(\$ 399,7 \varpi)$ & $(\$ 494,963)$ & $(\$ 551,507)$ & $(\$ 555,846)$ \\
\hline
\end{tabular}


Projected Revenues

Club Memberships
Green Fees
Total Cart Fees
Target Range Fees
Putting Course Fees
Golf Shop Sales
Food \& Beverage Sales

Total Projected Revenues

\section{Projected Costs and Expenses:}

Operational Expenses

Employee salries w/ benefits

Golf Cart

Marketing

URI Discounted Rounds

Replacement Reserve

Departmental

Golf Shop

Target Range

Putting Course

Food \& Beverage

Total Facility Expenses

Net Operating Income

(Before Debt Service)

Less Annual Debt Service

Proflt / Loss After Debt Service

Cummulative Deficlt / Profit

\section{$\underline{\text { Year } 1} \quad \underline{\text { Year } 2} \quad \underline{\text { Year } 3} \quad \underline{\text { Year } 4} \quad \underline{\text { Year } 5}$}

$\begin{array}{rrrrr}\$ 0 & \$ 0 & \$ 0 & \$ 0 & \$ 0 \\ \$ 506,252 & \$ 639,564 & \$ 777,459 & \$ 858,821 & \$ 966,512 \\ \$ 92,985 & \$ 117,148 & \$ 139,728 & \$ 154,350 & \$ 170,806 \\ \$ 108,500 & \$ 133,000 & \$ 165,550 & \$ 182,875 & \$ 210,000 \\ \$ 59,520 & \$ 72,960 & \$ 92,880 & \$ 102,600 & \$ 120,000 \\ \$ 38,744 & \$ 50,025 & \$ 59,116 & \$ 68,864 & \$ 75,821 \\ \$ 51,658 & \$ 66,489 & \$ 79,179 & \$ 91,819 & \$ 101,234 \\ \$ 857,660 & \$ 1,079,187 & \$ 1,313,911 & \$ 1,459,329 & \$ 1,644,373\end{array}$

$\$ 187,255$

$\$ 196,618$

$\$ 206,449$

$\$ 216,771$

$\$ 227,610$

$\$ 223,465$

$\$ 234,638$

$\$ 246,370$

$\$ 48,905$

$\$ 12,500$

$\$ 25,000$

$\$ 41,002$

$\$ 18,750$

$\$ 78,975$

$\$ 99,772$

$\$ 121,284$

$\$ 26,278$

$\$ 258,689$

$\$ 54,023$

$\$ 6,250$

$\$ 133,976$

$\$ 29,187$

$\$ 271,623$

$\$ 59,782$

$\$ 6,250$

$\$ 150,776$

$\$ 32,887$

$\$ 27,896 \quad \$ 36,018$

$\$ 42,563$

$\$ 49,582$

$\$ 54,591$

$\$ 32,550 \quad \$ 39,900$

$\$ 11,904 \quad \$ 14,592$

$\$ 49,665$

$\$ 18,576$

$\$ 25,829$

$\$ 33,245$

$\$ 645,419$

$\$ 39,589$

$\$ 812,179$

$\$ 54,863$

$\$ 63,000$

$\$ 24,000$

$\$ 20,520$

$\$ 50,617$

$\$ 45,909$

$\$ 941,136$

$\$ 212,241 \quad \$ 353,860$

$\$ 501,732$

$\$ 589,560$

$\$ 703,237$

$\$ 210,000 \quad \$ 210,000 \quad \$ 210,000 \quad \$ 210,000 \quad \$ 210,000$

$\$ 2,241 \quad \$ 143,860$

$\$ 291,732 \quad \$ 379,560$

$\$ 493,237$

$\$ 2,241 \quad \$ 146,101$

$\$ 437,833$

$\$ 817,393$

$\$ 1,310,630$

\subsection{Proforma Conclusions}

The results of the "worst case scenario" proforma projections in Table 6.4A are not promising and suggest that the project is not economically viable. The net operating income (NOI) prior to debt service for year one is a negative $\$ 24,134$. Years two through five showing gradual improvement as revenues start to stabilize. The financial performance of the course after annual debt service is dismal however with a cumulative deficit of $\$ 555,846$ after five years. The implications of these 
findings on the overall feasibility of the proposed course is severe. It is clear from this analysis that the proposed golf course will not be a "financial asset" to the University, if it performs at the lower end of the market share estimate range established in Chapter Five.

The results of the "best case scenario" proforma projections in Table 6.4B are extremely promising. The NOI prior to debt service is positive in all five years. The financial performance of the course after annual debt service also looks strong. It is anticipated that the proposed course will show a small profit after debt service of $\$ 2,241$ in year one. By the time revenues stabilize in year five the course will have earned a cumulative profit of $\$ 1,310,630$ for the University. It is equally clear from this analysis that the proposed golf course could be a strong financial asset to the University, if it performs at the higher end of the market share estimate range developed in Chapter Five.

In the final analysis, the feasibility study presents two very divergent projections which fail to clearly answer the fundamental question established in Chapter One, "Will the project work?" In my opinion neither of the ranges presented above are likely outcomes. The purpose of the range was to educate project proponents and key University decision makers about the financial risk and potential economic reward associated with a project of this type.

In an attempt to clarify the projections established above, I have developed an additional proforma projection which should help draw a more definitive conclusion regarding the financial feasibility of the proposed course. This analysis is a mid- 
range projection which is consistent with my market share estimate conclusions found at the end of Chapter Five. This projection assumes the course will generate 33,000 golf rounds, 27,650 target range buckets, and 18,960 putting course rounds. The rounds mix, fees and operating expenses are assumed to be the similar to those presented in the Tables $6.3 \mathrm{~b}$ and 6.4B.

The results of the mid-range projections made in Table 6.5 are cautiously optimistic. The NOI prior to debt service is positive in all five years and increase from $\$ 62,848$ in year one to $\$ 423,912$ in year five. The financial performance of the course after annual debt service indicates a negative cash flow for years one, two and three. Starting in year four the golf course earns a small profit cumulative profit of $\$ 11,140$, which increases to $\$ 225,052$ in year five as revenues finally stabilize. This is sizable return which more than meets the "break-even" criteria established in Section 6.1. If the proposed course is viewed with a long term prospective it certainly has the potential to become "financial asset" to the University.

In my opinion Table 6.5 presents a realistic proforma projection for the first five years of operations of the proposed URI golf course. The proforma analysis is based on a reasonable market share estimate which I feel is attainable under current market conditions. The proforma analysis is also grounded on a realistic program budget which provides sufficient funding to ensure a high quality, professionally designed and constructed golf course facility. It is also important to note that the results of this proforma analysis are consistent with NGF (1989) findings which state, "in many cases, perhaps most, the cash flow for the first two or three years will be negative. The cumulative deficit should start to decrease after the second year." 
Table 6.5 - Proforma Projections (mid-range estimate)

Projected Revenues

Club Memberships
Green Fees
Total Cart Fees
Target Range Fees
Putting Course Fees
Golf Shop Sales
Food \& Beverage Sales

Total Projected Revenues

Projected Costs and Expenses:

Operational Expenses

Employee salries $w /$ benefits

Golf Cart

Marketing

URI Discounted Rounds

Replacement Reserve

Departmental

Golf Shop

Target Range

Putting Course

Food \& Beverage

Total Facility Expenses

Net Operating Income

(Before Debt Service)

Less Annual Debt Service

Profit / Loss After Debt Service

Cummulative Deficit / Profit

\section{$\underline{\text { Year } 1 \quad \underline{\text { Year } 2}}$}

$\begin{array}{rr}\$ 0 & \$ 0 \\ \$ 401,016 & \$ 506,616 \\ \$ 73,656 & \$ 92,796 \\ \$ 85,715 & \$ 105,070 \\ \$ 47,021 & \$ 57,638 \\ \$ 30,690 & \$ 39,626 \\ \$ 40,920 & \$ 52,668 \\ \$ \$ 679,018 & \$ 854,415\end{array}$

Year 3

$\$ 0$

$\$ 615,846$

$\$ 110,682$

$\$ 130,785$

$\$ 73,375$

$\$ 46,827$

$\$ 62,720$

$\$ 1,040,235$

$\$ 187,255$

$\$ 223,465$

$\$ 25,780$

$\$ 25,000$

$\$ 76,995$

$\$ 0$

$$
\begin{array}{r}
\$ 196,618 \\
\$ 234,638 \\
\$ 32,479 \\
\$ 18,750 \\
\$ 97,270 \\
\$ 8,544
\end{array}
$$

$\$ 22,097$

$\$ 28,531$

$\$ 25,715$

$\$ 9,404$

$\$ 31,521$

$\$ 11,528$

$\$ 26,334$

$\$ 20,460$

$\$ 616,170$

$\$ 686,213$

$\$ 62,848$

$\$ 168,202$

$\$ 206,449$

$\$ 246,370$

$\$ 38,739$

$\$ 12,500$

$\$ 118,242$

$\$ 20,805$

$\$ 33,715$

$\$ 39,235$

$\$ 14,675$

$\$ 31,360$

$\$ 762,090$

$\$ 278,144$

$\$ 210,000 \quad \$ 210,000$

$\$ 210,000$

$(\$ 147,152) \quad(\$ 41,798)$

$\$ 68,144$

$(\$ 147,152) \quad(\$ 188,950)$
$(\$ 120,806)$
$\$ 210,000$

$\$ 210,000$

$\$ 131,946$

$\$ 213,912$

$\$ 227,610$

$\$ 271,623$

$\$ 47,355$

$\$ 6,250$

$\$ 146,995$

$\$ 26,037$

$\$ 43,243$

$\$ 49,770$

$\$ 18,960$

$\$ 40,095$

$\$ 877,938$

$\$ 423,912$

$\$ 341,946$

$\$ 11,140$

$\$ 225,052$ 


\subsection{Project Financing}

As of this writing no specific financing plan has been established for the proposed project. Some potential scenarios have been presented and for the purpose of this analysis the author has assumed the following. The total program cost for the project has been established at $\$ 3,392,172$. This figure includes the total cost to plan, design, permit, construct, and equip the course including a one year grow-in phase. This figure also includes all carrying costs associated with construction financing during the 18-month construction period. It is assumed that the construction loan will be through a private lender at commercial market rates.

It anticipated that the University will raise approximately $\$ 400,000$ through private donations to cover the preconstruction planning and design phase. Thus, at the completion of the construction phase of the project the University will require approximately $\$ 3,000,000$ in long term capital financing.

The mostly frequently referenced source of long term funding for the proposed project is tax-free Industrial Development Revenue Bonds issued by the Rhode Island Industrial Facilities Corporation (RIIFC). The proposed project could potentially be financed through the Industrial-Recreational Building Authority (IRBA) program. Under this program the IRBA is empowered to finance "recreational projects", which are defined under the IRBA ACT to mean any building, facility, development, or improvements designed in whole or in part to attract tourists to the state including facilities such as golf courses (Carolan, 1994). 
These loan are limited to $\$ 5,000,000$ per qualified project and are restricted to 75 percent of the total cost of the project. It is assumed that the University's 25 percent equity requirement would be met by offering the proposed site as collateral. Interests rates on tax-free municipal bonds vary depending on the length of the loan. For the sake of this analysis interest rates were assumed to be two points below. prime, or approximately 6.5 percent for a 10 -year bond issue. Underwriting fees vary from $\$ 16$ to $\$ 18$ per $\$ 1,000$ of bonds issued (Carolan, 1995). Thus, underwriting fees of approximately $\$ 50,000$ can be expected. For real estate financing, the annual mortgage insurance premium charged by the IRBA is currently 1.25 percent of the principal amount outstanding under the insured mortgage (Carolan, 1995).

It is anticipated that the University will capitalize all the fees and premiums associated with the bond issue. Based on these assumptions annual debt service for the proposed project is estimated at $\$ 210,000$. It is important to note that any IRBA funded golf course must be completely accessible to the general public (Connery, 1994). This means that a semi-private operating structure which incorporates a limited number of memberships for faculty, staff, and students is probably prohibited under a public financing scenario. 


\subsection{References}

Muirhead Desmond and Guy Rando. 1994. Golf Course Development and Real Estate. The Urban land institute. Washington, D.C.

Personal Interview. Kenneth Kermes. Vice President, Finance and Development, University of Rhode Island. July 21, 1995.

Devine, Barry and R.A. Casagrande. The University of Rhode Island College of Resource Development Golf Course Educational and Research Facility: A Project Overview. Kingston, RI. August 3, 1994.

National Golf Foundation. 1989. Guidelines for Planning and Developing a Public Golf Course. Jupiter, Florida. National Golf Foundation.

Connery, Thomas. 1994. A Narrative Real Estate Appraisal for the Newport National Golf Club. Golf Realty Advisors, Inc.

Massachusetts.

Devine and Casagrande. 1994. Start-up Budget for the University of Rhode Island Educational Golf Course and Research Facility. Kington, RI.

Personal Interview. Richard Carolan. President, Carolan and Company, Inc. August $1,1995$. 
CHAPTER SEVEN - CONCLUSIONS 


\subsection{Introduction}

The purpose of this chapter is to summarize the key findings from each of the six previous chapters, in order to arrive at a final "build" versus "no build" recommendation. This will be followed by a section which identifies the ancillary benefits associated with developing the proposed golf course which are not factored into this analysis. Finally, I will identify a number of important issues for future study and consideration.

\subsection{Summary of Key Findings}

In Chapter One the reader was given background information regarding the proposed project including a list of key project proponents, project objectives, and the basic project layout and key features. Next, the reader was introduced to the purpose, objectives, methodology, and limitations of the feasibility study .

The brief synopsis of the University's history found in Chapter two demonstrated that certain trends have remained constant throughout the URI's evolution. First, the three fundamental postulates of a land grant institution (teaching, research, and service), although heavily modified by technological and social changes, are still the foundation of the University's mission.

Second, the University from its inception in 1892 has historically suffered from a lack of financial resources, which has adversely affected its ability to become a first rate academic and research institution. This trend will most likely continue 
unless the University creates significant new funding sources outside of state aid and tuition revenues.

Third, the objectives of the proposed project as outlined by Devine and Casagrande (1994) are consistent with both the Carother's five year strategic plan and the University's mission as a land grant institution.

In Chapter Three the location of the proposed course was established and the general characteristics of the proposed site were outlined. The site was found to be approximately 230 acres in size with an extremely diversified mix of existing land uses including agricultural lands, upland forest, a sand and gravel pit, and an abandoned solid waste landfill. These three distinct ecosystems will make the course visually and physically interesting for golf course designers, URI researchers, and players. On a negative note the long axis of the 60 -acre upland forested parcel was found to be on an east-west alignment which is not the preferred solar orientation for golf course development.

Chapter Three closed with a review of the regulatory requirements which case study analysis suggests will be a crucial element of the golf course development process. It is highly likely that the proposed project will face a formal and lengthy wetland's application and review process under the Rhode Island Department of Environmental Management. Under this application the Town of South Kingstown will also be granted significant input into the review process. The Town planner indicated that the proposed site resides in a Ground Water Protection Zone which could make the project controversial with the general public. At the federal level the 
project will probably face only limited review by the US Army Corps of Engineers, if the design goals of "no wetland impacts" is maintained.

The site inventory and analysis conducted in Chapter Four generated a number of interesting conclusions regarding the feasibility of the proposed site for golf course development. The results of the slope analysis were generally positive and generated two key findings. No portion of the site was found to be constrained by steep slopes, except for small portions of the excavation sites in the gravel bank area. A field inspection of the agricultural fields suggests that they fall into the "extremely flat" category which means they will require considerable filling and shaping to create features and avoid drainage problems.

The surface and groundwater analysis indicated that there is sufficient groundwater capacity within the Chipuxet aquifer to meet the project's irrigation needs. Moreover, there are other small ponds within or adjacent to the site which could serve as both potential water sources and course features. This section also found that water consumption concerns as well as other environmental impacts generated a tremendous amount of controversy for the URI Cogeneration Project which was the last major project put forward by the University. A case study analysis of the cogeneration project would provide insight into the regulatory hurdles and significant local issues which the proposed URI golf course will face.

The findings of soils analysis provided mixed conclusions. First, the agricultural field is comprised of slightly constrained, or high quality soils, which should mitigate drainage concerns resulting from the areas extremely flat profile. 
Portions of the soils in the gravel bank, disposal area, and upland forested areas suffer from a variety of constraints including high stone content, high water tables, unstable soils, and a lack of topsoil and substratum material. All these conditions impacted the program budget for the proposed facility.

The results of the vegetation analysis were generally positive with one notable exception. The best available information suggests that the wooded swamp in the upland forested portion of the proposed site is significantly larger than indicated on the Preliminary Concept Plan for the facility. In addition the stream within the wetland's area was found to be wider than $10^{\prime}$ and thus will require a $200^{\prime}$ setback. These two findings impact the amount of usable land available for the course construction.

The findings of the circulation and access analysis were mixed. The proposed site was found to be fairly accessible and convenient to a number of major roadways. From a visibility standpoint the proposed site was found to be isolated from Route 138 , and thus will not get the benefit of "drive-by" traffic exposure. Because of this problem money was budgeted within the program and operating budgets for an aggressive signage and marketing campaign. A review of the Preliminary Concept Plan also noted a number of site circulation and design issues which should be addressed as the design progresses.

The final part of this chapter summarized the findings and implications of the EPA Final Listings Report (FLR) for the URI Disposal Area/West Kingston Dump. The study found that the site is in the early stages of a long EPA Superfund cleanup 
process (minimum six years) which will have significant adverse effects on the location, design, permitting, schedule, construction, and cost of the proposed golf course. In addition, the FLR indicates that the groundwater has been locally contaminated by a leachate plume which originates from the disposal sites and has migrated west towards Hundred Acre Pond. This section also found that the remediation element of the proposed golf course is an opportunity for the University to participate in the Superfund process, and help tailor a cost-effective design solution which minimizes its liability.

The results of the market analysis conducted in Chapter Five generated a number of interesting conclusions regarding the market demand for the proposed course. The 1995 market area demand summary indicates a potential of 944,177 public golf rounds. This figure is comprised of market area residents, visiting tourists, and URI student, staff, faculty and alumni.

The market supply analysis found 26 existing courses, and two planned courses within a 20 mile radius of the proposed URI golf course. In general terms, the overall quality of the existing courses in the market area was found to be below average. While there were a few notable exceptions, the majority of the courses were pre-1970's courses which do not meet modern design standards. These 28 courses supply the market area with an estimated 922,000 public golf rounds.

An estimated market potential figure of 22,177 public golf rounds was then established by comparing these two figures. This relatively small figure is not enough to support a new daily fee course, (which typically requires approximately 40,000 
rounds), and suggests that the golf market is in a relative state of equilibrium. Limited market area demand also suggests that the proposed course could only survive by drawing play away from other courses.

Fortunately, the findings of the market supply analysis indicate that the market is ripe for the development of a new golf course designed and built to modern standards. The basic assumption underlying this theory is that a modern high quality golf facility will draw play away from older, poorer quality courses with comparable fee structures. The golf course inventory identified 12 existing golf courses within the market area which are below the anticipated quality of the proposed course.

To test this theory a simple market share estimate model was developed and a "best case scenario" estimate of 41,660 rounds, and "worst case scenario" estimate of 25,000 rounds was calculated. The chapter ended with my own market share estimate of 33,000 rounds which was based on certain market considerations and management concerns.

The results of the financial assessment in Chapter Six are cautiously optimistic and support the overall feasibility of the proposed course. The chapter began with a review of the University's financial goals for the proposed project. This review concluded that no definitive financial expectations have been established for the proposed project. For the purpose of this analysis it was assumed that the proposed course must at least break even (after revenues stabilize), in order for the University to consider proceeding with the project. 
The next section established the total program budget of $\$ 3,392,172$ to plan, design, permit, construct, and equip the proposed golf course including a one year "grow-in" phase. The program budget was broken down into three major components: First, the construction budget which includes the hard costs to build the facility is estimated to cost $\$ 2,533,000$. Second, the owner-furnished equipment and furnishing which are required to operate and maintain the facility is estimated to cost $\$ 175,000$. Third, soft costs such as design, construction, and professional fee's, and "grow-in" costs is estimated to be $\$ 522,640$.

This was followed by a proforma analysis which established the rounds mix, fee schedule, projected revenues and operating expenses for the proposed course. The worst and best case scenarios market share estimates were then run through the analysis to determine whether the project is feasible. The results of the "worst case scenario" proforma projections were not promising and suggest that the project is not economically viable, if it performs at the lower end of the market share estimate range. The results of the "best case scenario" proforma projections were extremely promising and suggest that the project could be a strong financial asset, if it performs at the higher end of the market share estimate range.

In an attempt to clarify these two divergent conclusions a mid-range projection consistent with the author's Chapter Five market share estimate was run through the model. The results of this projection were cautiously optimistic indicating a cumulative fifth year profit of $\$ 225,052$. This section concluded that the mid-range projection was a realistic conclusion supported by a reasonable market share estimate 
and program budget. The chapter ended with a discussion of the author's assumptions regrading long-term project financing.

\subsection{Final Recommendation}

The primary purpose of this feasibility study was to evaluate the proposed projects overall chance for success. In basic terms this study attempted to answer the fundamental real estate development question, "Will the project work?"

In simple terms the answer to the above referenced question is, YES. Based on the objectives, assumptions, and qualifications outlined in this study, it is my opinion that the proposed project is in fact feasible, and does have a good chance for success. In my opinion the University should build the proposed project.

I draw this conclusion with some reservations because of the number of constraints and issues which have been identified by this study. As the proforma projection using the "worst case scenario" market share estimate demonstrated the proposed project should not be considered a risk free venture with guaranteed profits.

In particular, I would like to call attention to the remediation element of the proposed project, which I feel will have a significant impact on the location, design, permitting, schedule, construction, and cost of the proposed golf course. The study has not successfully quantified the full impact of the Superfund site on the feasibility of the project. Moreover, I feel strongly that the complexity, cost, and duration of the remediation process has the potential to dominate and undermine the rest of the 
proposed project. I do not recommend abandoning the remediation element of the project, but isolating its impacts on the project through careful planning and design.

\subsection{Ancillary Benefits}

To arrive at the build recommendation the study focused on three specific objectives: site inventory and analysis of the proposed site; market study which evaluated the market demand for a new golf course; and a financial assessment which tested the economic viability of the proposed project. The study had a private sector bent which was narrowly focused on the "traditional" components of a feasibility analysis.

In hindsight, this approach disregarded the project's public sector or University setting. As the study progressed it became clear that this narrow focus prevented me from considering a number of important "ancillary benefits" which the proposed project will bring to the University. These ancillary benefits are not easily quantified, and thus do not lend themself to a proforma style analysis. It is extremely important, however, for the University to consider these ancillary benefits in order to reach an educated decision regarding the overall feasibility of the proposed project.

In my opinion, it is reasonable to assume that the proposed project will generate the following ancillary benefits for the University:

a. The proposed project has an important academic, research, and outreach focus which is inherently important to the University's mission as a land grant institution.

b. The proposed project will generate new opportunities for grant supported research in the areas of pest control, turfgrass, wetlands 
restoration, landfill remediation, ecological restoration, golf course maintenance, GIS/CAD design, and landscape architecture.

c. The proposed golf course will be an excellent venue for some of the University's numerous fund raising events.

d. The course will help generate alumni visits to the Kingston campus, particularly for local alumni from the Rhode Island, Connecticut, and Massachusetts area who number in the 30,000 range. These visits will help improve the linkage between the University and its alumni community and should improve fund raising activities.

e. The proposed course and its associated educational, athletic, and recreational programs will provide the University with a first rate marketing tool to attract future students.

f. The proposed course will provide the University with an opportunity to expand and improve relations with South Kingstown and other surrounding communities.

g. The proposed project offers the University a chance to assist the State and the EPA in tailoring a cost effective remediation plan which mitigates their potential liability.

\subsection{Issues For Future Consideration and Study}

A number of important issues which directly affect the feasibility of the proposed course have been identified throughout this study. Where possible, these issues have been addressed in the context of the study, but many still require additional research. There are also many issues which went beyond the scope of this study. Throughout the course of my research I developed the following unprioritized list of issues which I feel warrant additional study and consideration:

a. The University should attempt to quantify and value the importance of the ancillary benefits referenced above. 
b. The University should hire a certified golf course architect to evaluate the proposed site.

c. A formal business plan should be developed for the project which includes project goals, financial expectations, a financing plan, and detailed project proforma.

d. The University needs to investigate alternate development and management scenarios for the proposed golf course. These alternatives should address the management and permitting concerns referenced early in this study

e. The University needs to examine the irrigation requirements of the proposed project to ensure that the Chipuxet aquifer can safely meet the needs. This examination should look carefully at the issues which arouse during the URI Cogeneration Project.

f. A detailed survey of the proposed site should be conducted including a wetlands delineation in order to determine the amount of usable land.

g. Additional research is required on the Superfund remediation element of the proposed project. This research should focus on the duration, cost, and scope of the clean-up process.

h. The University should investigate the type(s) and amounts of fertilizers used by the existing turfgrass operations. This information should then be compared to the anticipated fertilizer and pesticides requirements of the proposed golf course. This information will be useful in mitigating local pollution concerns during the approval process.

i. The University needs to develop a master program schedule for this project which includes milestones for all major planning, permitting, design, construction and start-up activities.

j. The University should conduct a formal siting study to determine whether the proposed site is the best location for the URI golf course. 